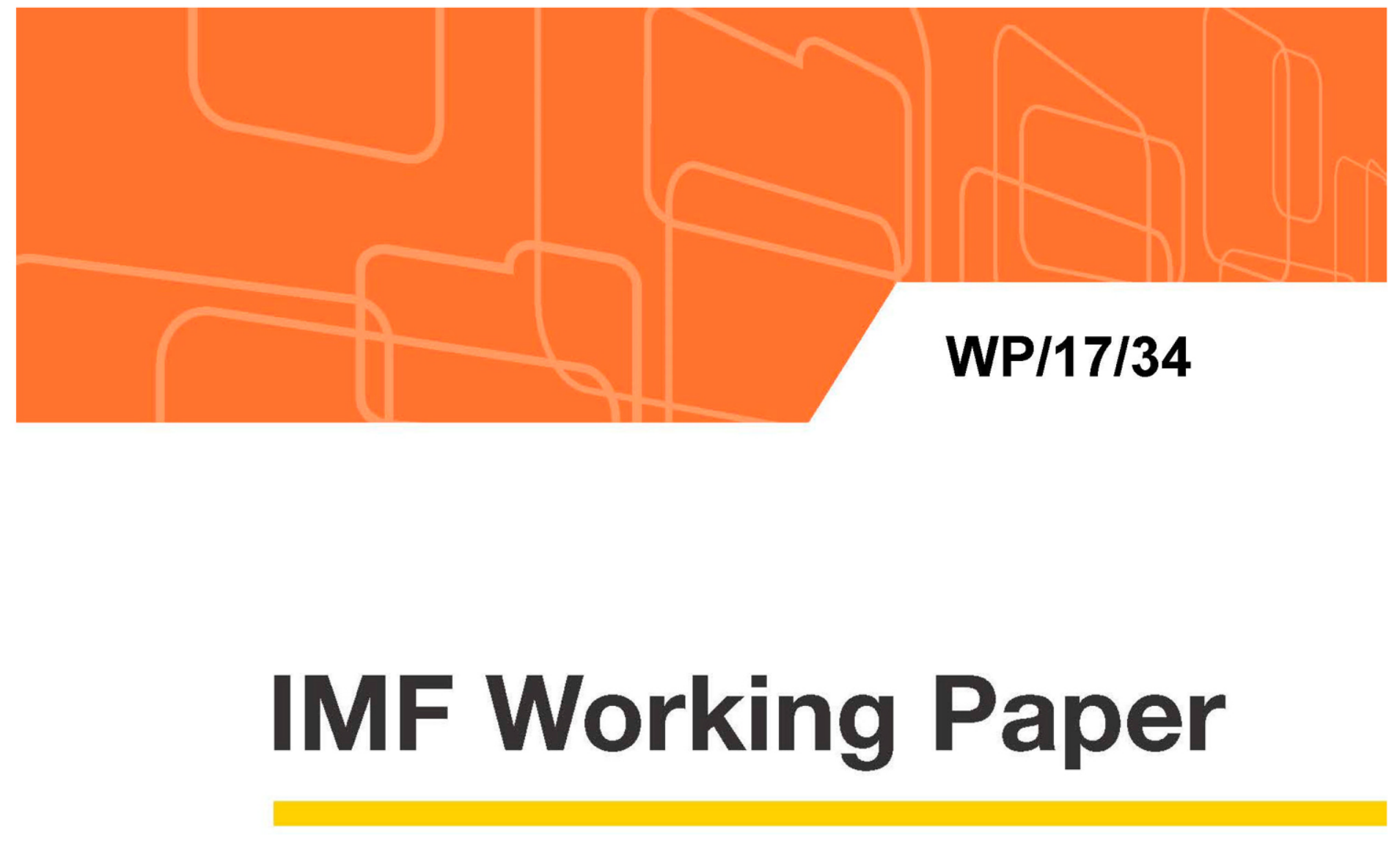

\title{
Women at Work in Latin America and the Caribbean
}

by Natalija Novta and Joyce Cheng Wong

IMF Working Papers describe research in progress by the author(s) and are published to elicit comments and to encourage debate. The views expressed in IMF Working Papers are those of the author(s) and do not necessarily represent the views of the IMF, its Executive Board, or IMF management. 


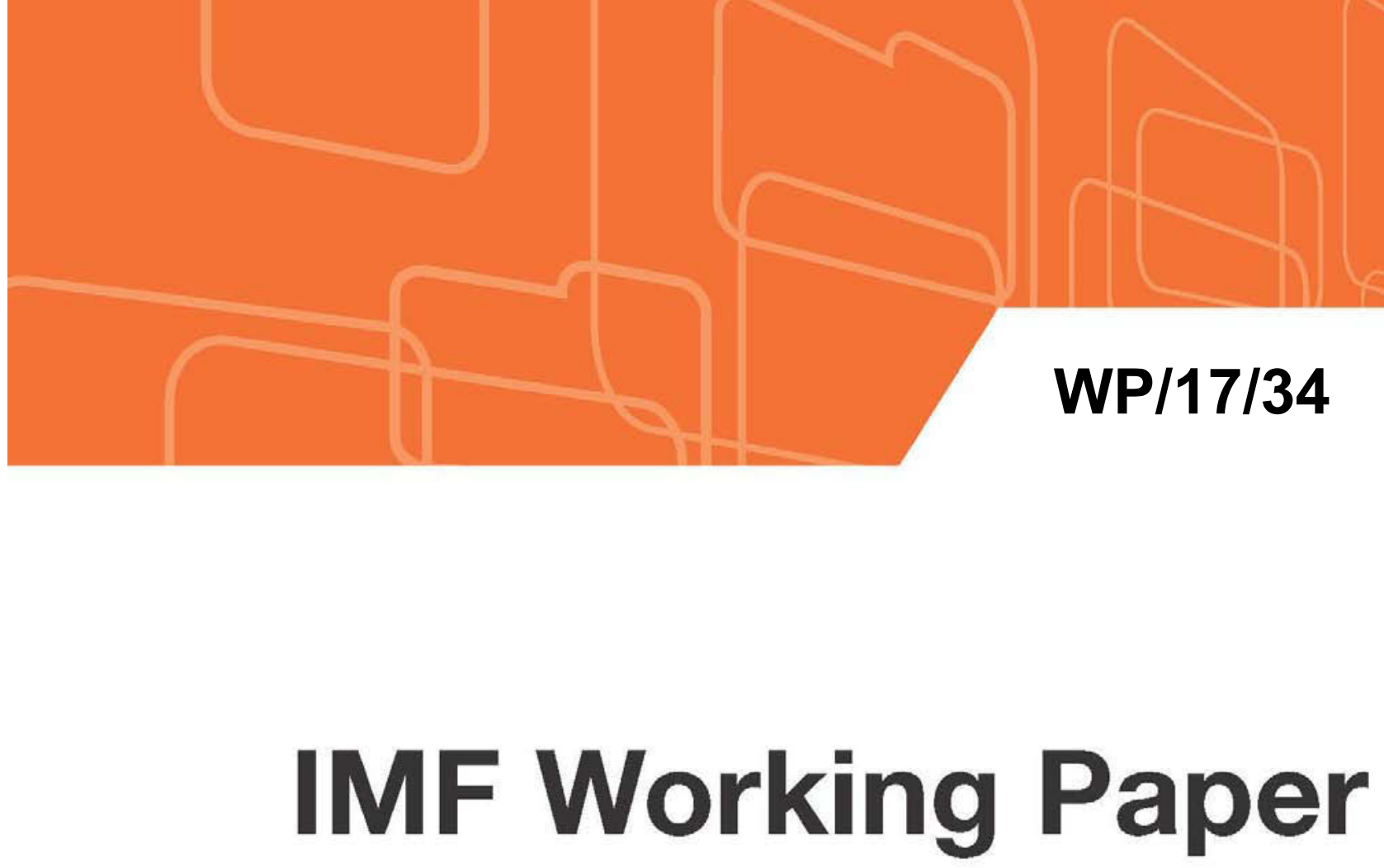

\section{Women at Work in Latin America and the Caribbean}

by Natalija Novta and Joyce Cheng Wong

IMF Working Papers describe research in progress by the author(s) and are published to elicit comments and to encourage debate. The views expressed in IMF Working Papers are those of the author(s) and do not necessarily represent the views of the IMF, its Executive Board, or IMF management.

I N T E R N A T I O N A L M O N E T A R Y F F U N D 


\title{
IMF Working Paper
}

Western Hemisphere Department

\section{Women at Work in Latin America and the Caribbean ${ }^{1}$ \\ Prepared by Natalija Novta and Joyce Cheng Wong}

Authorized for distribution by Hamid Faruqee and Uma Ramakrishnan

February 2017

\section{IMF Working Papers describe research in progress by the author(s) and are published to elicit comments and to encourage debate. The views expressed in IMF Working Papers are those of the author(s) and do not necessarily represent the views of the IMF, its Executive Board, or IMF management.}

\begin{abstract}
Women across the world remain an underutilized resource in the labor force. Participation in the labor force averages around 80 percent for men but only 50 percent for women - nearly half of women's productive potential remains untapped compared to one-fifth for men. Latin America and the Caribbean (LAC), as a region, saw the largest gains in female labor force participation (LFP) in the world during the last two decades. Women in LAC are becoming increasingly active in paid work, closing the gap with men and catching up to their counterparts in advanced economies at an impressive rate. In this paper, we document the recent trends in female LFP and female education in the LAC region, discuss the size of potential gains to GDP from increasing female LFP and policies which could be deployed towards this goal.
\end{abstract}

JEL Classification Numbers: J16, J20, J40, J48

Keywords: Economics of gender, Women's labor supply, Public policy affecting female LFP Author's E-Mail Address: NNovta@imf.org; JWong2@imf.org

\footnotetext{
${ }^{1}$ Authors are grateful to Pelin Berkmen, Hamid Faruquee and Alejandro Werner for very helpful guidance and comments, and to Steve Brito and Genevieve Lindow for excellent research assistance. Very useful comments were also provided by and Marcelo Estevao, Bertrand Gruss, Nicole Laframboise, Izabela Karpowicz and Monique Newiak. All errors are our own.
} 


\section{INTRODUCTION}

Given the historically low levels of total factor productivity (TFP) in the Latin America and the Caribbean (LAC) region, tapping the full potential of human capital and labor is of utmost importance. With approximately half of women in LAC not participating in the labor force, increasing female labor force participation (LFP) stands out as one of the under-tapped engines of growth. Note that while these women are not engaged in market work, most of them do unpaid work, typically as caregivers in their own home, even though their skills may be used more efficiently and productively outside the home. As women become more educated - and the share of women with a college education now exceeds that of men in several LAC economies - their productivity at work becomes ever higher, as do the potential losses to GDP growth if they remain outside of the labor force.

Countries in LAC have made momentous strides in increasing female LFP, especially in South America. And while the female LFP rate has traditionally been very high for some countries - for example in the Caribbean - gender gaps still exist throughout the region. To some extent female LFP depends on economic development, but policies also matter. For a given development level of a country, there is evidence that improvements in policies such as childcare and protected leave from work after childbirth can increase female participation in the labor force.

In recent years there have been many papers which have examined both the drivers of gender inequality, including but not limited to labor force participation (Gonzales et al. (2015a)), and the macroeconomic outcomes of gender inequality (including on growth, financial development, and income inequality more generally). Beginning with the seminal Greenwood and Jovanovic (1990), other papers which have examined the link between female LFP and growth and inequality include Amin and Kuntchev (2015) and Gonzales, et al. (2015b). Nevertheless, while there have been significant studies for female LFP for both advanced economies (in particular, the US) and Africa (e.g. Hakura et al. (2016)), there remains a dearth of papers in this topic for the Latin America region.

In this context, this paper's contribution is three-fold: (i) we seek to document where LAC is today in terms of female LFP and its recent evolution, (ii) we present simple "back-of-theenvelope" estimates for gains in GDP that could be reaped from higher female LFP and (iii) we discuss policies which have been shown to generate positive effects in the female LFP.

Throughout this paper we focus on labor force participation rates because they tend to be more comparable across countries than employment and unemployment rates, where specific country definitions may vary. We use ILO estimates of LFP data from 1990-2014. Estimates of LFP do not distinguish between formal or informal work, i.e. both are included. ${ }^{2}$ Also, due to data constraints, we abstract from the gender gap in wages, i.e. the difference in remuneration between men and women, although anecdotal evidence points to significant

\footnotetext{
${ }^{2}$ There are, however, gender differences in informal work, with more women than men participating in the informal sector. Analysis of gender differences in informality is beyond the scope of this paper. For a discussion of informal employment in Latin America, including gender differences, see Freije (2001).
} 
gap in this area in LAC. While cross-country data on labor income of men and women are now becoming available for a bigger set of countries (see Hausmann et al 2009, and Schwab et al 2015 of the World Economic Forum), historical estimates of the gender gap in wages (especially for developing countries) remain very scarce.

The paper is organized as follows. Section II presents stylized facts on the recent trends in female and male labor force participation rates and gender gap (i.e. the difference between male and female LFP); section III documents the U-shaped relationship between female LFP and log GDP per capita, and discusses how female LFP is linked to the process of economic development; section IV analyzes LFP by age and education; section V discusses policies that may increase female labor force participation; section VI presents a back-of-theenvelope estimate of the possible macroeconomic impact of increasing female LFP in LAC; and section VII discusses the potential cyclical responses of female LFP. Section VIII concludes.

\section{TRENDS IN FEMALE AND MALE LABOR FORCE PARTICIPATION}

The LFP statistics are computed per the equation below: it is the sum of all employed and unemployed aged 15 and above, divided by the total non-institutionalized population aged 15 and above. A few points worth mentioning are: (i) because retired people exit the labor force, LFP depends negatively on the proportion of retired people within the group of those aged 15 and above, so economies with a higher proportion of older populations, all else equal, will have a lower LFP rate; (ii) being in the labor force does not mean that a person is employed - unemployed people are part of the labor force; and (iii) the ratio excludes institutionalized people (such as prisoners).

$$
L F P=\frac{\text { Employed }_{\text {aged } 15 \text { and above }}+\text { Unemployed }_{\text {aged } 15 \text { and obove }}}{\text { Population }_{\text {aged } 15 \text { and above }}}
$$

In 1990 only 44 percent of women in LAC participated in the labor force. In 2014 this ratio increased to 54 percent, close to levels seen in the United States and EM Asia. This is a remarkable feat. This improvement in LAC was the largest of any region in the world, driven by a broad-based improvement in all LAC subregions but especially for the five largest South American economies (Figure 1). 
Figure 1. Female Labor Force Participation Rates across the World

(Average; percent)

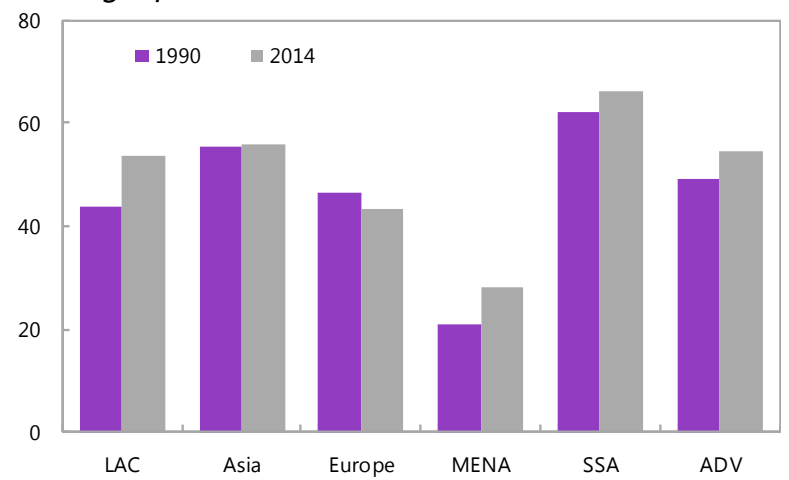

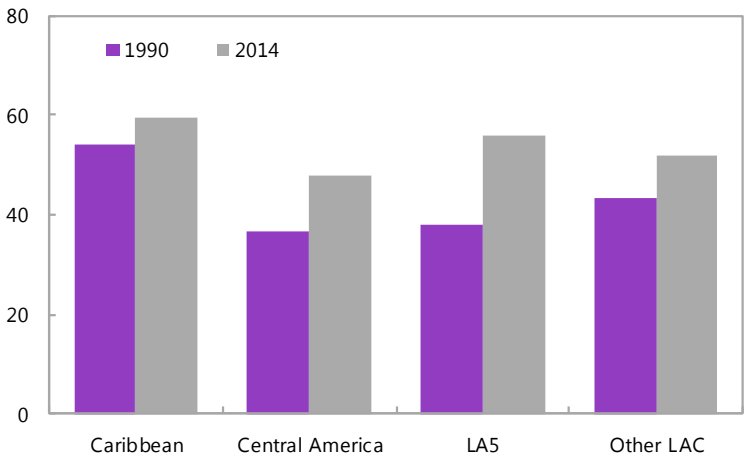

Sources: World Bank, World Development Indicators database; and IMF staff calculations.

Note: $\mathrm{LAC}=$ Latin America and the Caribbean; Asia = Emerging and Developing Asia; Europe = Emerging and Developing Europe; MENA = Middle East and North Africa; SSA = Sub-Saharan Africa; and ADV = Advanced Economies.

As noted above, there is significant heterogeneity in female LFP among LAC subregions. For example, Caribbean countries have historically had high female LFP rates, even above those of the United States. Central America and the five largest South American economies started with low female LFP in the early 1990s, at below 40 percent. Since then, countries in South America have recorded significant gains, while Central America has been catching up at a more modest rate (Figure 2). LAC as a whole has now approached the United States and Emerging and Developing Asia in terms of female labor force participation rates (Figure 2). ${ }^{3}$

Figure 2. Female Labor Force Participation Rate (Percent)

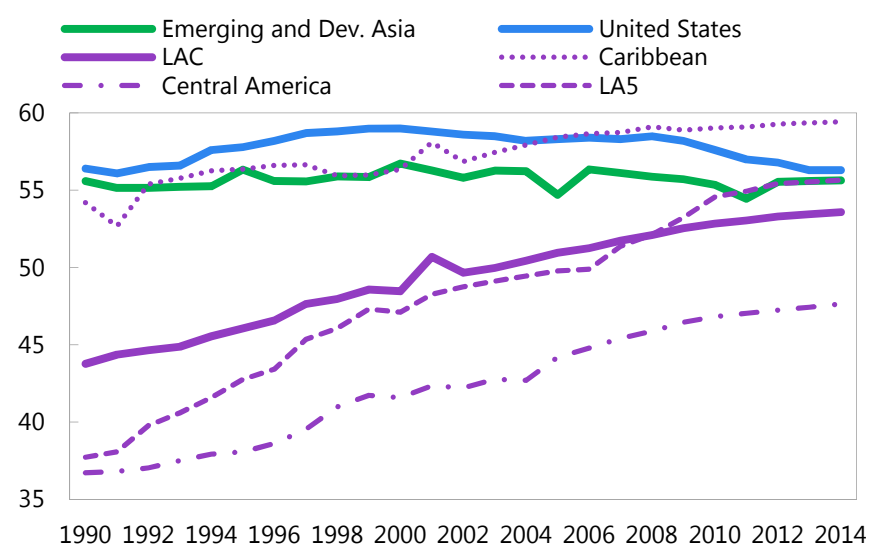

Examining the gender gap in LFP (calculated as the difference between the male and female LFP in each region), we find that the gender gap is still large in LAC versus other regions (Figure 3), despite the momentous improvements over the last two decades. In fact, it is interesting to note that the levels of female LFP are now quite similar across the different

\footnotetext{
${ }^{3}$ While female LFP rates in the US have been declining since 2008, this pattern actually begun before the recession and is primarily linked to structural changes including longer time spent on education and higher retirement rates of women as baby boomers reach 65 years old (Canon et al. 2015).
} 
regions in the world. Instead, the large gender gap in LAC is driven by the very high male LFP in the region (which averages nearly 80 percent, versus 68 percent in advanced economies).

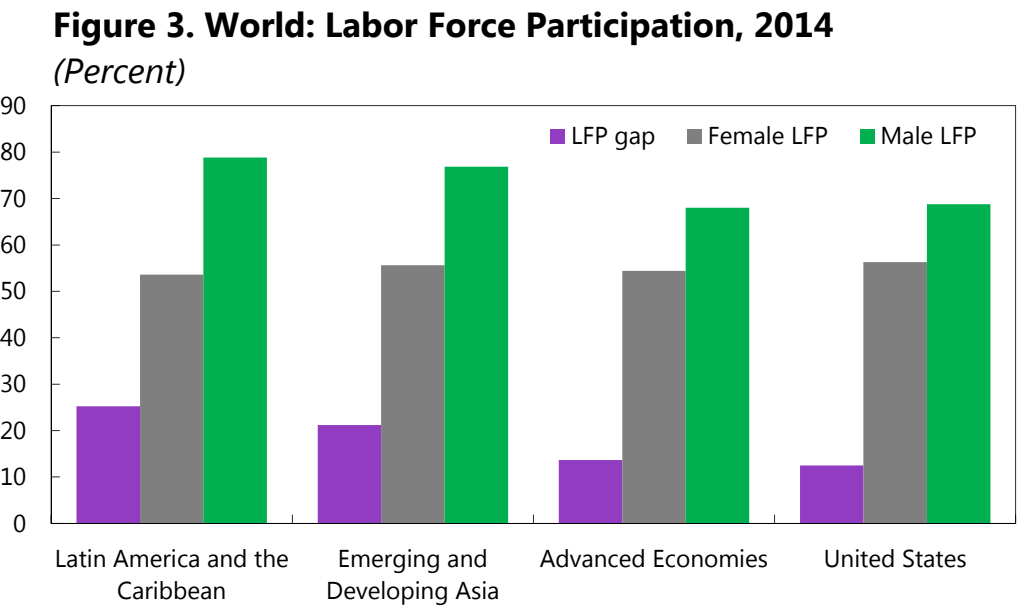

Sources: World Bank, World Development Indicators database; and IMF staff calculations. Note: LFP = labor force participation

To better understand drivers of male and female LFP in LAC, including demographics, we run a cross-section regression of male LFP on log GDP per capita, the square of log GDP per capita and the share of population over 65, using 2014 data for 170 countries. We find that the share of population over 65 is a significant predictor of male LFP - this is quite natural since, in most of the world, men during their working age, by default work at a paid job. Thus, the younger the population, the larger the proportion of men who, all else equal, are likely to work. In order to quantify how this affects the gender gap, we assume that each LAC country has the same share of population over the age of 65 as the U.S., and we predict LAC male LFP in this new demographic scenario by using the regression coefficients estimated above. The implied gender gap is then calculated from this "older population" male LFP minus the actual observed female LFP in each LAC country. ${ }^{4}$

Figure 4 displays both the actual gender gap in LFP, as well as the implied gender gap in LFP if demographics in LAC were the same as those in U.S. In that case, as the figure shows, the gender gap in LAC would be significantly reduced in most LAC sub-regions, with the exception of CAPDR. Examining the largest LAC economies, we also note that while the demographics account for a significant difference in LFP gaps vis-à-vis the US for some countries (Brazil, Colombia, Peru, and Uruguay), for others (Argentina, Chile, and in particular Mexico) the gender gap remains significant.

\footnotetext{
${ }^{4}$ We ran the same regression for female LFP, as for male LFP. However, with female LFP as the dependent variable, the coefficient on the share of population over 65 was not statistically significant and it was economically small. Hence, when calculating the implied LFP gap, we decided to use the actual female LFP, rather than predicted female LFP, since the key variable in this exercise - demographics - is not a useful predictor of female LFP.
} 
Figure 4. Gender gaps in Latin America and the Caribbean remain large. (gender gaps in labor force participation, 2014, percent)

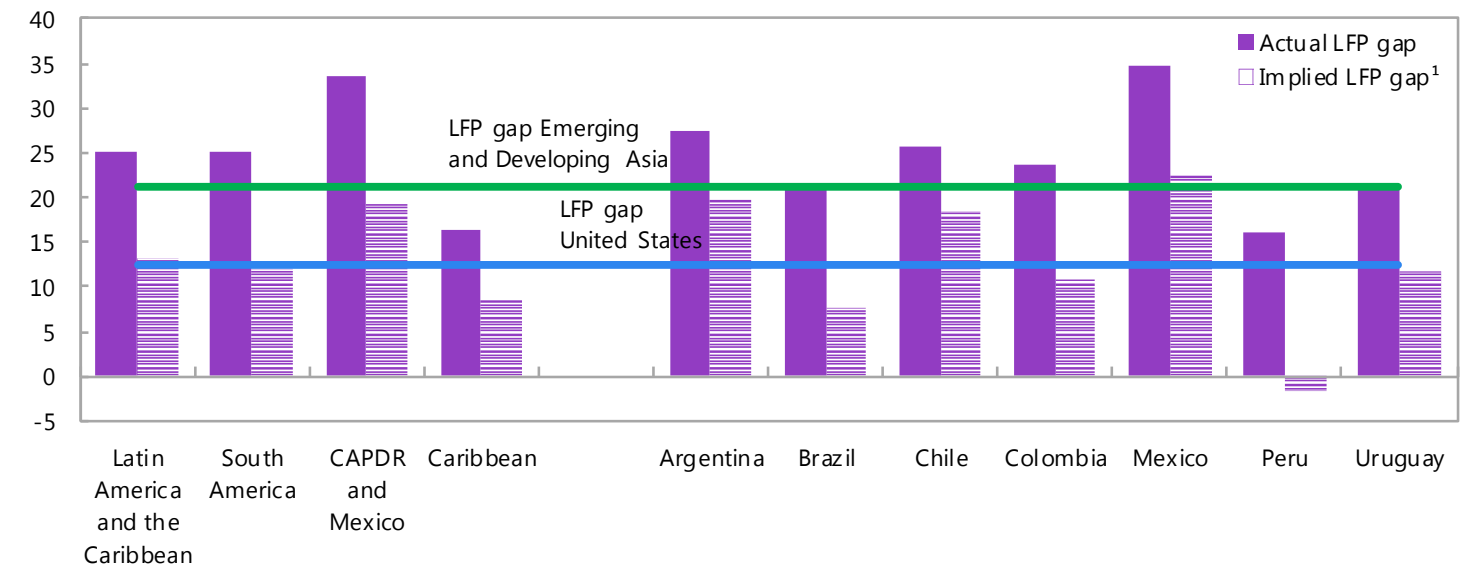

Sources: World Bank, World Development Indicators database; and IMF staff calculations.

Note: CAPDR = Costa Rica, Dominican Republic, El Salvador, Guatemala, Honduras, Nicaragua, and Panama; LFP = labor force participation.

${ }^{1}$ Values predicted using U.S. demographics (percent of those over 65).

To examine the country by country heterogeneity in more detail, Figure 5 below plots the male LFP, female LFP and the gender gap in LFP for each LAC country. A few interesting patterns spring to the fore. For countries with significant gender gaps (e.g., CAPDR and Mexico), we see that this is indeed driven by a combination of both low female LFP and high male LFP. On the other extreme, for countries in LAC with very small gender gaps such as the Caribbean countries, this pattern is also driven by a combination of female and male LFP rates - in this case, extremely high female LFP but relatively low male LFP.

Figure 5. Labor Force Participation, by gender, and the gender gap (Percent)

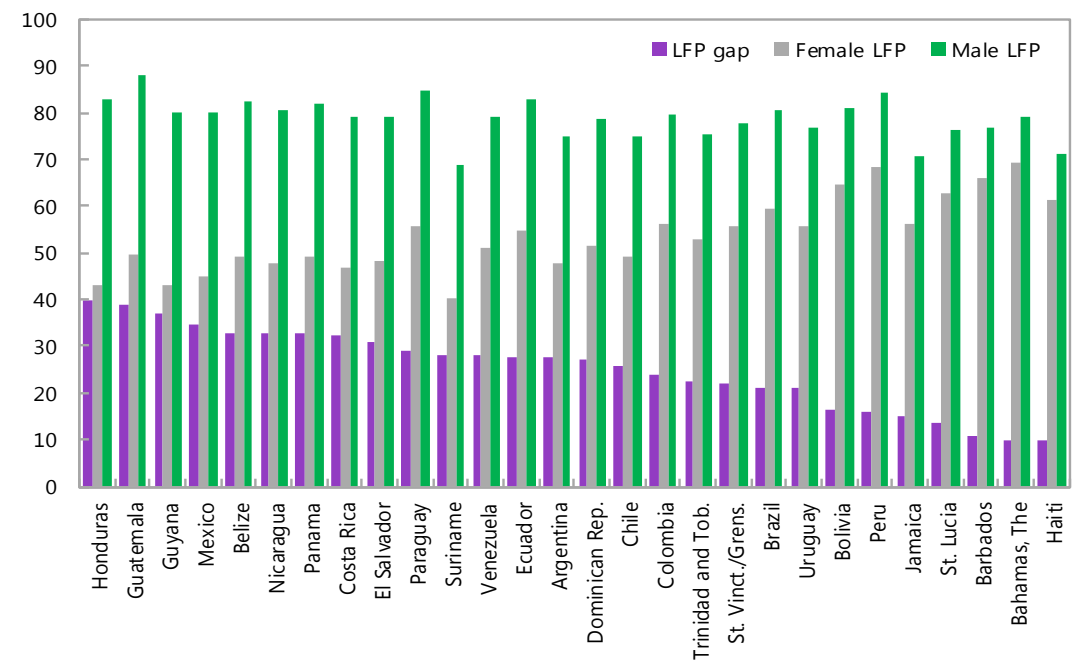

Sources: World Bank, World Development Indicators database; and IMF staff calculations. Note: LFP = labor force participation. 


\section{DEVELOPMENT LEVEL AND LABOR FORCE PARTICIPATION}

There is a well-documented U-shaped relationship between female LFP and log GDP per capita (Goldin 1994, Cagatay and Ozler 1995). This U-shaped relationship reflects three stages of development. In the poorest economies, in addition to their unpaid work at home, women tend to work outside the home as much as men, driven partly by low levels of urbanization and high prevalence of agricultural work; this combination allows the women to easily transition between home and market (agricultural) work as the physical distance between home and market work is small. At low levels of development, the income effect also dominates, where the woman's earnings play a key role in household expenditures.

As development levels and household incomes rise, and while women's earning potential is not yet high enough (potentially due to a gender wage gap), more women decide to stay at home and focus on providing childcare (i.e. the substitution effect dominates). Thus, female LFP tends to be lower among the middle income economies, and they are at the bottom of the U-shaped curve. Finally, as income and education levels rise further and many educated women pivot towards their "comparative advantage" towards "brain-heavy" occupations, they then choose to enter the labor force and seek professional childcare services, thereby raising female LFP. At this stage, economies move to the upward sloping part of the Ushaped curve, where female LFP increases with log GDP per capita.

Beyond the development effect, however, other factors drive female LFP and will help determine whether a country lies "above" or "below" the U-shaped curve. For example, the first panel in Figure 6 shows that in 1980, LAC countries tended to be below the estimated Ushaped curve. In other words, female LFP of LAC countries in 1980 was generally lower than what would be predicted by their development level. We see that by 2010 a majority of LAC countries have moved above the estimated curve. This suggests that, even though LAC countries continue to be at the bottom of the U-shaped curve (due to their middle-income status), their improvement in female LFP over time was greater than that of countries from other regions and was driven by improvements beyond development levels. 
Figure 6. Female Labor Force Participation and log GPD per Capita

1980

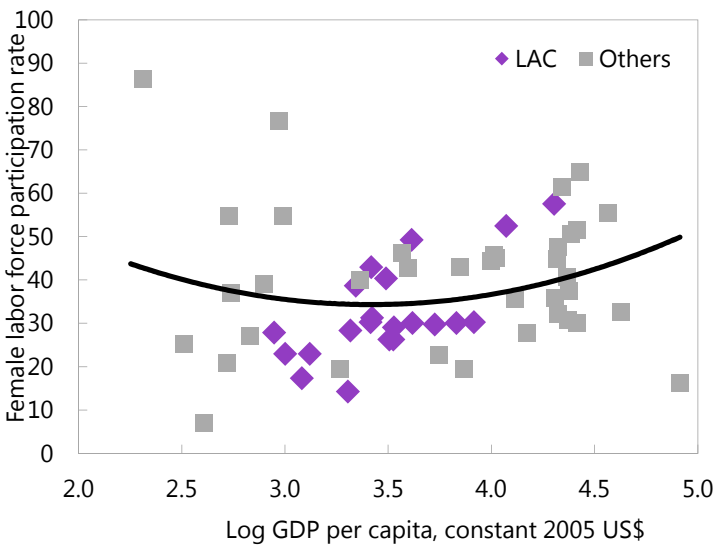

2000

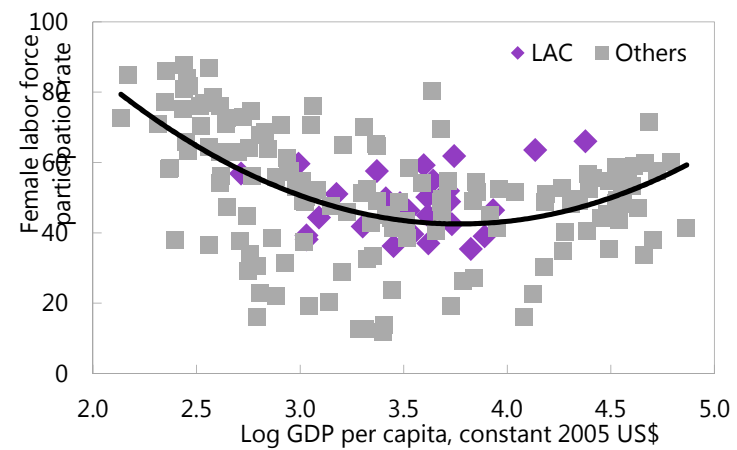

1990

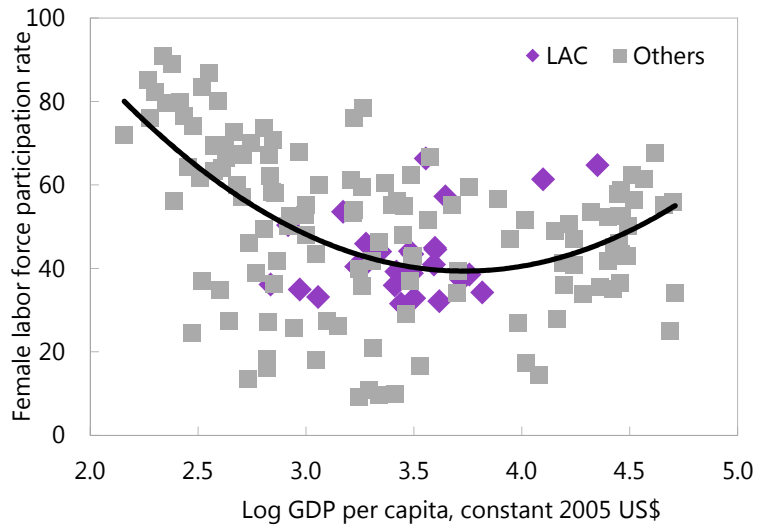

2010

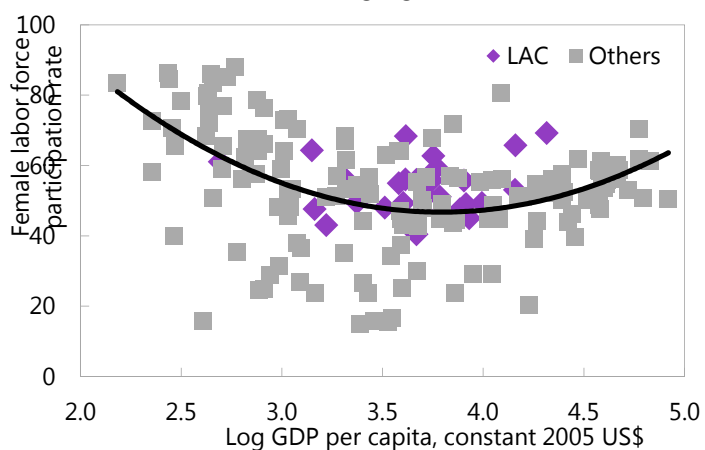

Sources: World Bank, World Development Indicators database; and IMF staff calculations.

It is interesting to note that while female LFP and economic development have a U-shaped relationship (and variations in female LFP rates are significant across countries), the relationship between log GDP per capita and male LFP exhibits no such behavior. Higher log GDP per capita is instead linearly associated with lower male LFP (Figure 7). Furthermore, the variation in male LFP is relatively small - nearly all the countries except a handful have male LFP rates between 60 and 80 percent. ${ }^{5}$ These patterns hint to a significant difference between male and female labor supply - while the latter's net outcome depends on whether the income or the substitution effect dominates as women's wages rise, in the case of male participation, as men's wages increase with GDP per capita, the substitution effect seems to rule, as men shift into leisure.

\footnotetext{
${ }^{5}$ Separating male LFP across decades does not yield changes across time, neither in the general negative relationship between male LFP and GDP per capita, nor for LAC countries' relative position in the trendline.
} 
Figure 7. Male LFP and log GDP per Capita.

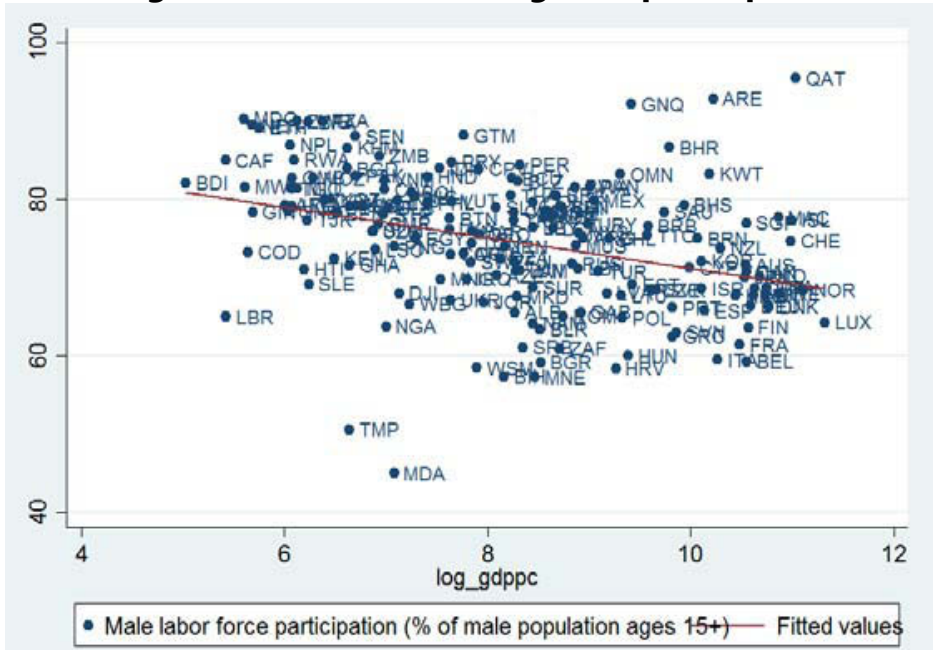

IV. Education, Age, AND FEMALE LFP

Beyond development, another significant driver of female LFP is education. This factor is especially important because it plays a dual role: it both drives more women to work and increases the productivity of those who do. Women's education levels in Latin America are on the rise, and greater female education tends to be associated with higher female LFP. Furthermore, higher levels of education also mean that, when women participate in the labor force, they are less likely to engage in unprotected (informal) work, such as domestic help. Of course, while this paper focuses on female LFP as the main economic outcome of interest, the literature has also found that more educated mothers lead to higher human capital in children, thus fostering a virtuous intergenerational cycle (Currie and Moretti, 2003).

Using the latest available household survey data for the six largest LAC economies, ${ }^{6}$ we see that women aged 25-34 are now, on average, more educated than men in the same age group (see Figure 8). On average, 34 percent of women in those ages have a college education, compared to 31 percent of the men. This is a significant break from the past - examining the cohort aged 55-65, we see that only 15 percent of women had college educations, compared to 18 percent of men.

\footnotetext{
${ }^{6}$ Survey years included 2013 (Chile and Brazil), 2014 (Mexico) and 2015 (Argentina, Colombia and Peru).
} 
Figure 8. Younger Women and Education Levels

(college education by age and sex, percent)

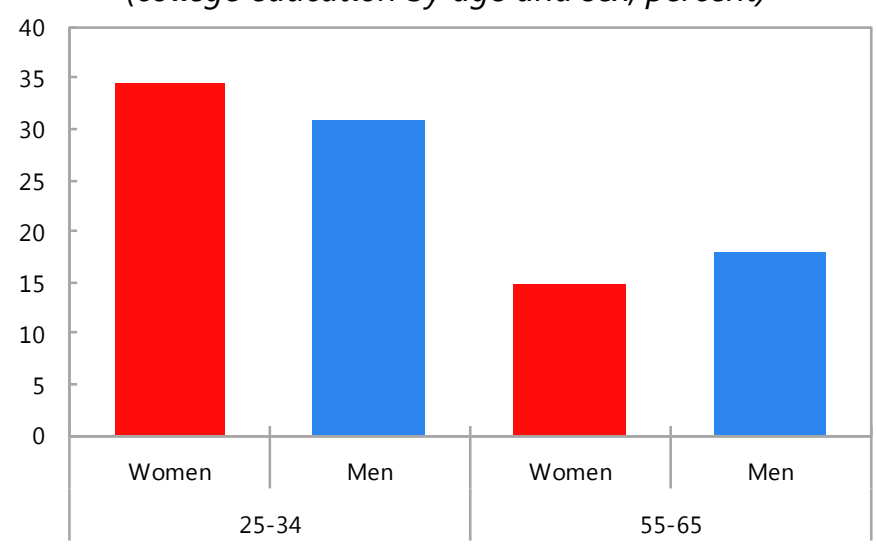

Sources: Household surveys; and IMF staff calculations

Note: Latest available data. Simple average of Brazil, Chile, Colombia, Mexico, Peru, and Uruguay. College = incomplete college or more.

As (young) women are becoming more educated, they are also more likely to participate in the labor force. Figure 9 shows labor force participation rates by age for men and women, with some college education or more, and with high school education or less. Comparing the higher educated men and women (blue lines), one can see that there is almost no gender difference in LFP in the 15-24 age group, while the gender gap increases broadly with age. For those with a high school degree or less (red lines), there is a more persistent gender gap throughout. As expected, there is variation in LFP across LAC countries, and across different ages and education levels. In Annex II, we present charts similar to Figure 9 separately for Brazil, Chile, Colombia, Mexico, Peru and Uruguay.

Figure 9. Younger, more educated women are working more

(labor force participation by age, sex, and education, percent)

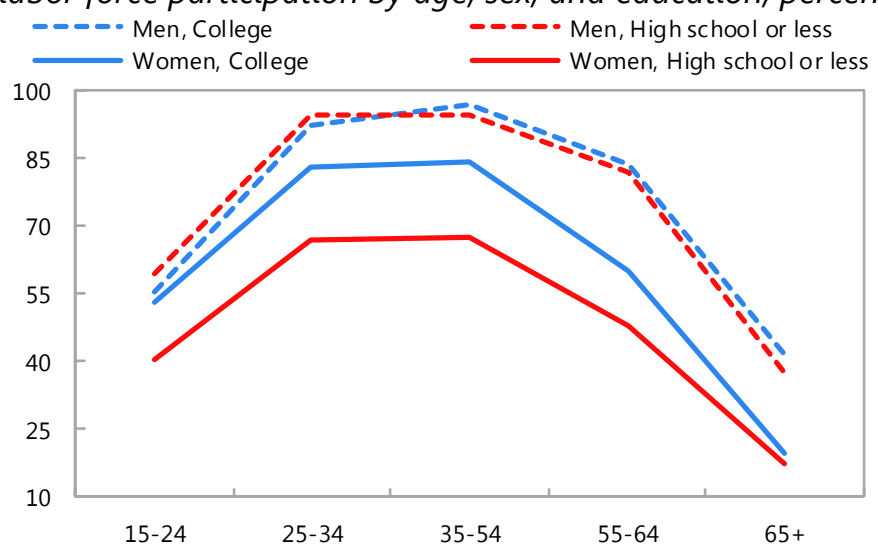

Sources: Household surveys; and IMF staff calculations.

Note: Latest available data. Simple average of Brazil, Chile, Colombia, Mexico, Peru, and Uruguay, College = incomplete college or more. High school or less $=$ high school education or less. 


\section{Policies that Could Raise Female LFP}

While macroeconomic fundamentals (which drive economic development) and education levels take a long time to change, this does not mean that policymakers cannot, in the shortterm influence female LFP outcomes. The literature shows that policies, particularly those involving the provision of childcare and maternity/paternity leave, can have significant shortterm effect on female LFP.

Ideally, one would want to use household survey data for countries where policy changes have taken place to investigate how various policies might affect the gender gap in labor force participation or female labor force participation directly. However, household survey data are relatively scarce for LAC countries, and for those who have it, one would need to identify an appropriate policy change and to have long-enough time series to track behavior before and after. Due to the lack of a time series for many of the policy variables, we chose to examine a cross section of countries in 2014, including advanced economies and emerging markets. While the cross-section regressions indicated what kinds of policies are associated with higher or lower gender gaps, we must bear in mind that these associations cannot be interpreted as causal, and are likely subject to omitted variable bias. In addition, we run panel regressions with women's legal rights, the only policy variable for which we have enough historical data (our sample is 1990-2010).

Table 1 presents some descriptive statistics for LAC and advanced economies on variables which might affect female LFP and the LFP gender gap. Note that while we use the advanced economies as a comparison benchmark in this table, we include other emerging markets in the regression sample. As noted before, the LFP gap is indeed nearly double that of advanced countries, while at the same time, the proportion of people over the age of 65 in LAC is less than half that of advanced countries. Educational levels for women in the region remain relatively low despite significant progress. An important factor on female LFP is also the level of transportation infrastructure, which helps women maintain market work without spending superfluous time outside the home. We see that the road quality variable (which we use as a proxy for infrastructure quality) still lags behind in LAC.

In terms of policy variables, it is interesting to note that while the region has broadly the same level of paid days of maternity leave as advanced economies, legal mandate for equal remuneration for equal work and non-discrimination based on gender are much weaker in LAC. Childcare payments are also less likely to be tax deductible in LAC, and the number of paternity days is lower. Although this is simply a comparison of averages, this does hint to potential areas where gains could be had in the region. 
Table 1. Summary statistics: Potential determinants of the gender gap in LFP

\begin{tabular}{|c|c|c|c|c|c|c|c|c|}
\hline & \multicolumn{4}{|c|}{ LAC (22 countries) } & \multicolumn{4}{|c|}{ Advanced ( 29 countries) } \\
\hline & Mean & $\begin{array}{l}\text { Std. } \\
\text { Dev. }\end{array}$ & Min & Max & Mean & $\begin{array}{l}\text { Std. } \\
\text { Dev. }\end{array}$ & Min & Max \\
\hline LFP gap & 26.29 & 7.86 & 10 & 39.8 & 13.56 & 4.01 & 7.1 & 22 \\
\hline Log GDP per capita & 8.31 & 0.81 & 6.2 & 9.57 & 10.36 & 0.5 & 9.18 & 11.33 \\
\hline Population ages 65 and above & 7.41 & 2.4 & 4.58 & 14.33 & 16.99 & 3.51 & 11.03 & 25.71 \\
\hline Roads quality (WEF) & 3.54 & 0.85 & 2.25 & 5.23 & 5.21 & 0.77 & 3.31 & 6.22 \\
\hline Female years of schooling (Barro-Lee) & 7.67 & 1.82 & 3.08 & 10.33 & 11.29 & 1.16 & 9 & 13.03 \\
\hline $\begin{array}{l}\text { Log of paid days of maternity leave } \\
\text { (World Bank) }\end{array}$ & 4.49 & 0.3 & 3.74 & 5.2 & 4.52 & 0.99 & 0 & 5.47 \\
\hline $\begin{array}{l}\text { Are parents entitled to flexible/part- } \\
\text { time schedules? (WB) }\end{array}$ & 0 & 0 & 0 & 0 & 0.45 & 0.51 & 0 & 1 \\
\hline $\begin{array}{l}\text { Does the law mandate equal } \\
\text { remuneration for work of equal } \\
\text { value? (WB) }\end{array}$ & 0.29 & 0.46 & 0 & 1 & 0.69 & 0.47 & 0 & 1 \\
\hline $\begin{array}{l}\text { Does the law mandate } \\
\text { nondiscrimination based on gender in } \\
\text { hiring? (WB) }\end{array}$ & 0.33 & 0.48 & 0 & 1 & 0.69 & 0.47 & 0 & 1 \\
\hline $\begin{array}{l}\text { Are childcare payments tax } \\
\text { deductible? (WB) }\end{array}$ & 0.14 & 0.36 & 0 & 1 & 0.34 & 0.48 & 0 & 1 \\
\hline $\begin{array}{l}\text { Does the government support or } \\
\text { provide childcare services? (WB) }\end{array}$ & 0.95 & 0.22 & 0 & 1 & 1 & 0 & 1 & 1 \\
\hline $\begin{array}{l}\text { Log of paid days of paternity leave } \\
\text { (WB) }\end{array}$ & 1.06 & 0.88 & 0 & 2.64 & 1.27 & 1.34 & 0 & 4.5 \\
\hline
\end{tabular}

Note: All variables marked (WB) come from Women, Business and the Law, World Bank (2016)

Turning to the regression results, presented in Table 2, we see that (as expected from the above discussion on the U-shape) log GDP and its square are the most significant predictors of the gender gap in LFP. In fact, the $\mathrm{R}^{2}$ in the first column of Table 2 suggests that GDP differences alone explain about a third of all variation in the gender gap in LFP. While demographics (as measured by share of population aged 65 and above) are important in predicting male LFP, they are not a statistically significant predictor female LFP, or consequently, of the gender gap in LFP. The quality of infrastructure, and roads, in particular, have been identified as a policy measure that could improve female LFP (Cubas, 2016, Black 2014). However, in a cross-country setting, the differences in road quality are not associated with a lower gender gap in LFP. Nevertheless, as discussed in Kochhar et al. (2016), cross-country regressions did find that investments in transportation and telecommunications have positive and significant coefficients on female labor force participation directly. 
In the next two subsections, we examine the regression findings for several of the included policy variables.

\section{A. Effective policies: women's legal rights and education}

We construct a policy index to measure women's legal rights using data from the World Bank publication entitled Women, Business and the Law (2016). The index is based on 11 variables, as detailed in Figure 10. Each of these variables is a binary variable, where a value of 1 indicates equal rights between men and women. The index is a sum of these variables. As we can see from Figure 10, on the aggregate, LAC countries do not exhibit significant differences from advanced economies in terms of women's rights. Nevertheless, while LAC performs relatively well in the enactment of laws supporting gender equality, there has been much discussion and evidence that the mere existence of laws does not ensure de facto gender equality due to weak enforcement. In many of these countries, women continue to face obstacles including lack of information about their rights, fear of retribution, inability to access courts and/or afford legal counsel (Goodwin and Whelan, 2015, Haas, 2010). As shown in Figure 11, the legal system is relatively inefficient in most LAC countries when compared to advanced economies. ${ }^{7}$ Thus, one should exert care when interpreting the small differences in the legal rights index below, keeping in mind that this reflects only enactment and not de facto implementation.

\section{Figure 10. Women's Legal Rights (average among countries)}

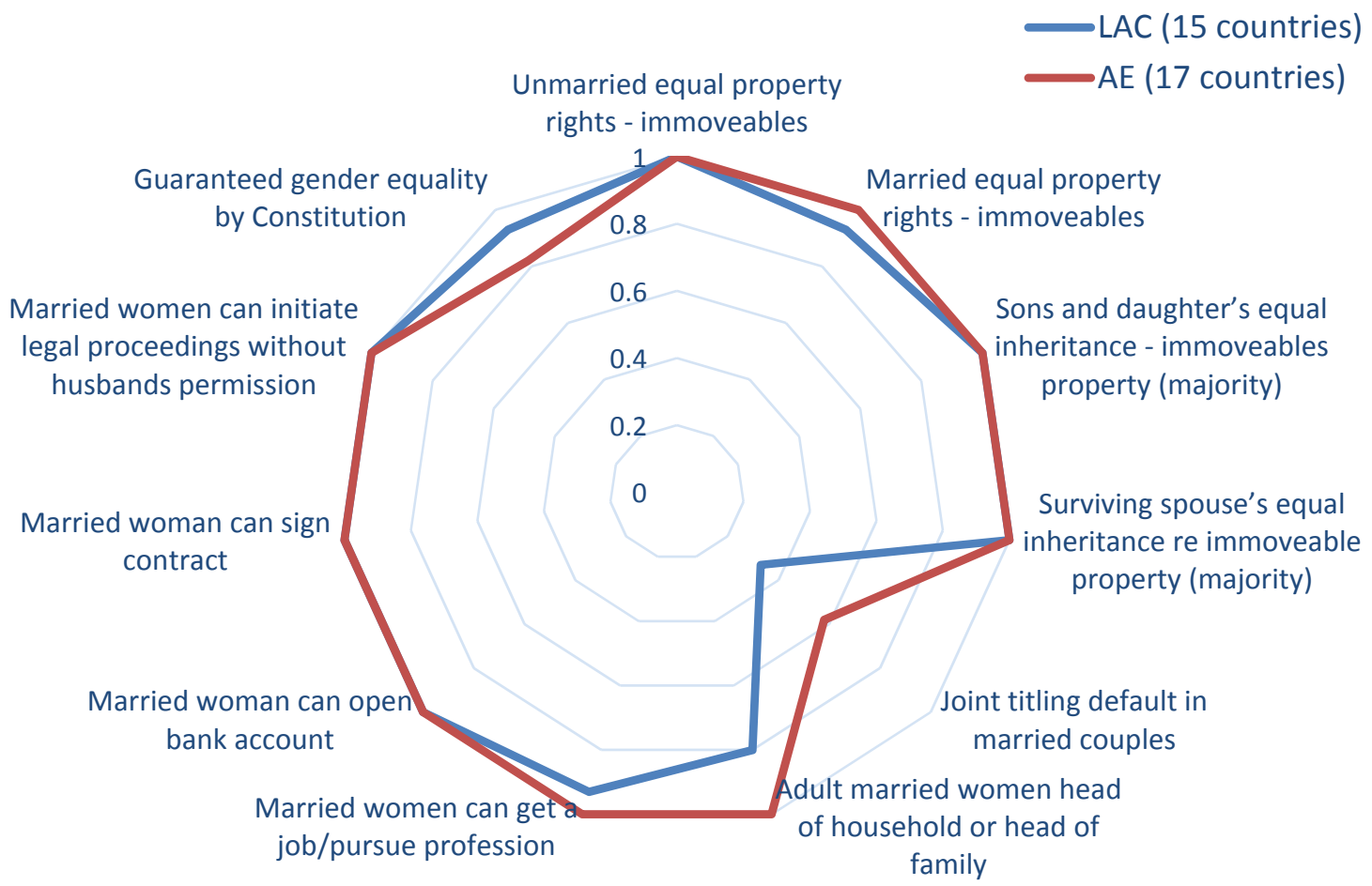

\footnotetext{
7 The World Justice Project Rule of Law Index takes into account dimensions such as constraints on government powers, corruption, open government, fundamental rights, order and security, regulatory enforcement, civil justice, and criminal justice.
} 
Figure 11. WJP Rule of Law Index (2015)

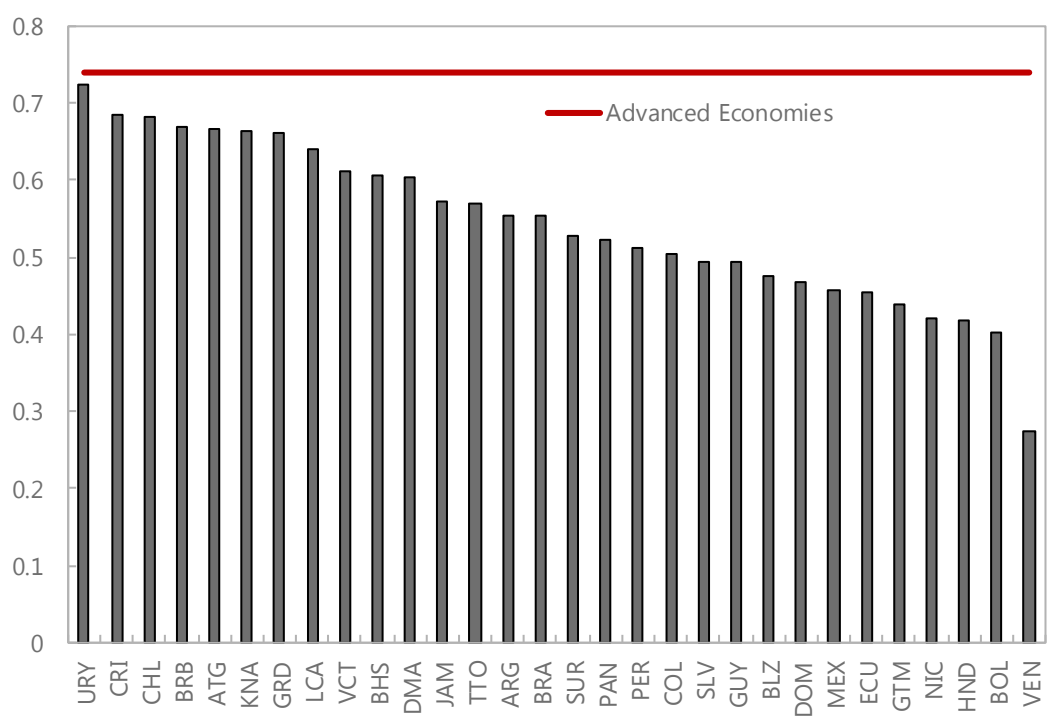

Even with the caveats cited above, both the women's legal rights index and female education are associated with lower gender gaps in LFP in the cross-section (Table 2). While we cannot assign causality, it seems intuitive that women tend to participate more in the labor force if they can control their assets, if they are constitutionally protected against discrimination etc.

Table 2. Correlates of gender gap in labor force participation - cross-section, 2014

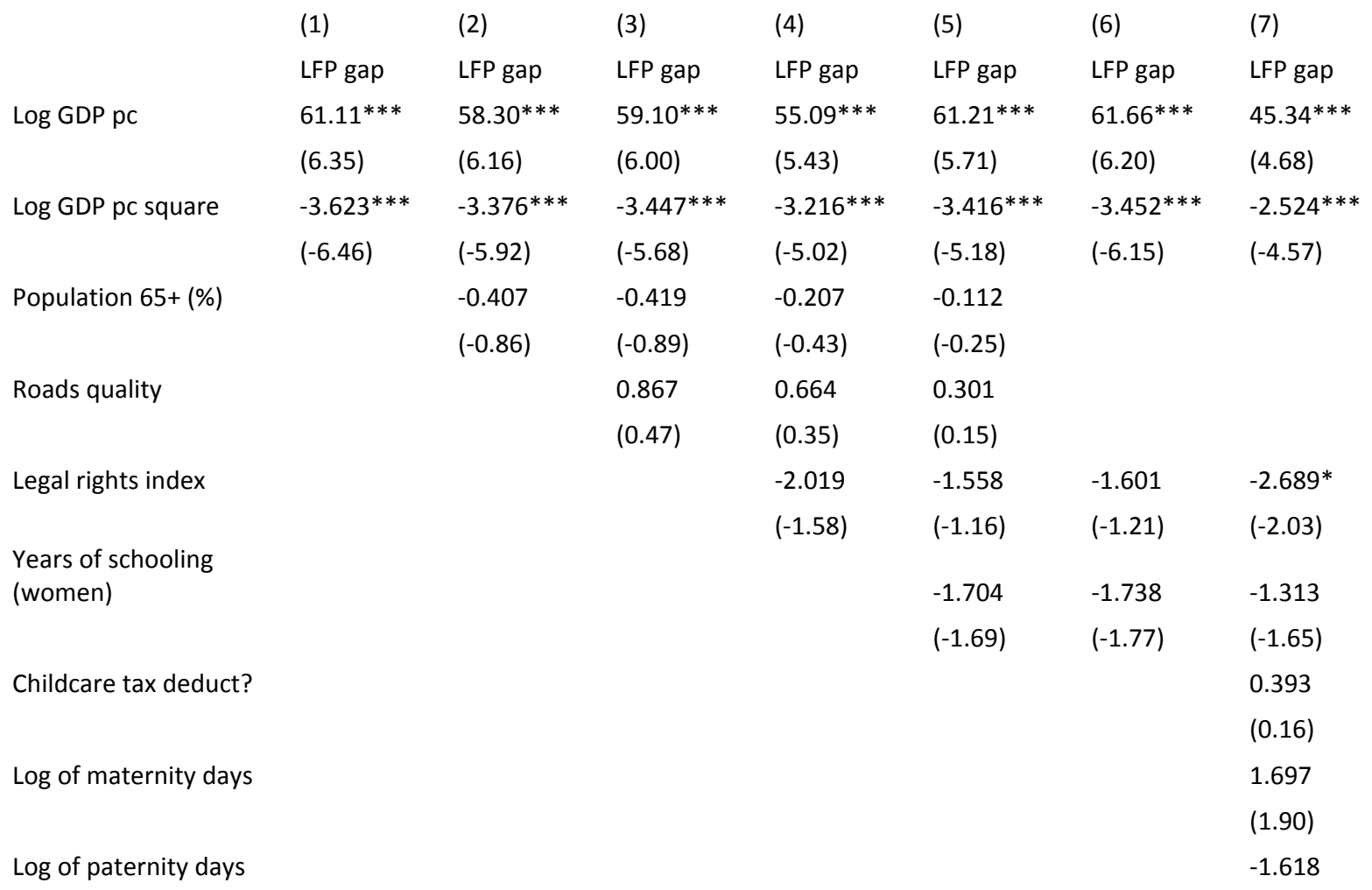




$\begin{array}{llllllll} & & & & (-1.09) \\ \text { Constant } & -228.3 * * * & -219.1 * * * & -224.0 * * * & -189.0 * * * & -216.7 * * * & -217.0 * * * & -145.7 * * \\ \text { Observations } & (-5.78) & (-5.67) & (-5.40) & (-3.96) & (-4.30) & (-4.80) & (-3.39) \\ \text { R-squared } & 77 & 77 & 77 & 77 & 77 & 77 & 89 \\ & 0.308 & 0.315 & 0.317 & 0.355 & 0.387 & 0.386 & 0.326\end{array}$

$\mathrm{t}$ statistics in parentheses, $* \mathrm{p}<0.05 * * \mathrm{p}<0.01 * * * \mathrm{p}<0.001$

Legal rights index and female years of schooling uses latest available values, 2010

Our limited panel results are presented in Table 3, using the legal rights index as the key policy variable. ${ }^{8}$ The explanatory power of the legal rights index becomes even stronger in panel regressions. Looking sub-components of the legal rights index, those that appear most relevant are equal inheritance of sons and daughters, not having joint titling as the default in married couples, and having gender equality guaranteed by the Constitution.

Table 3. Correlates of gender gap in labor force participation - panel, 1990-2010

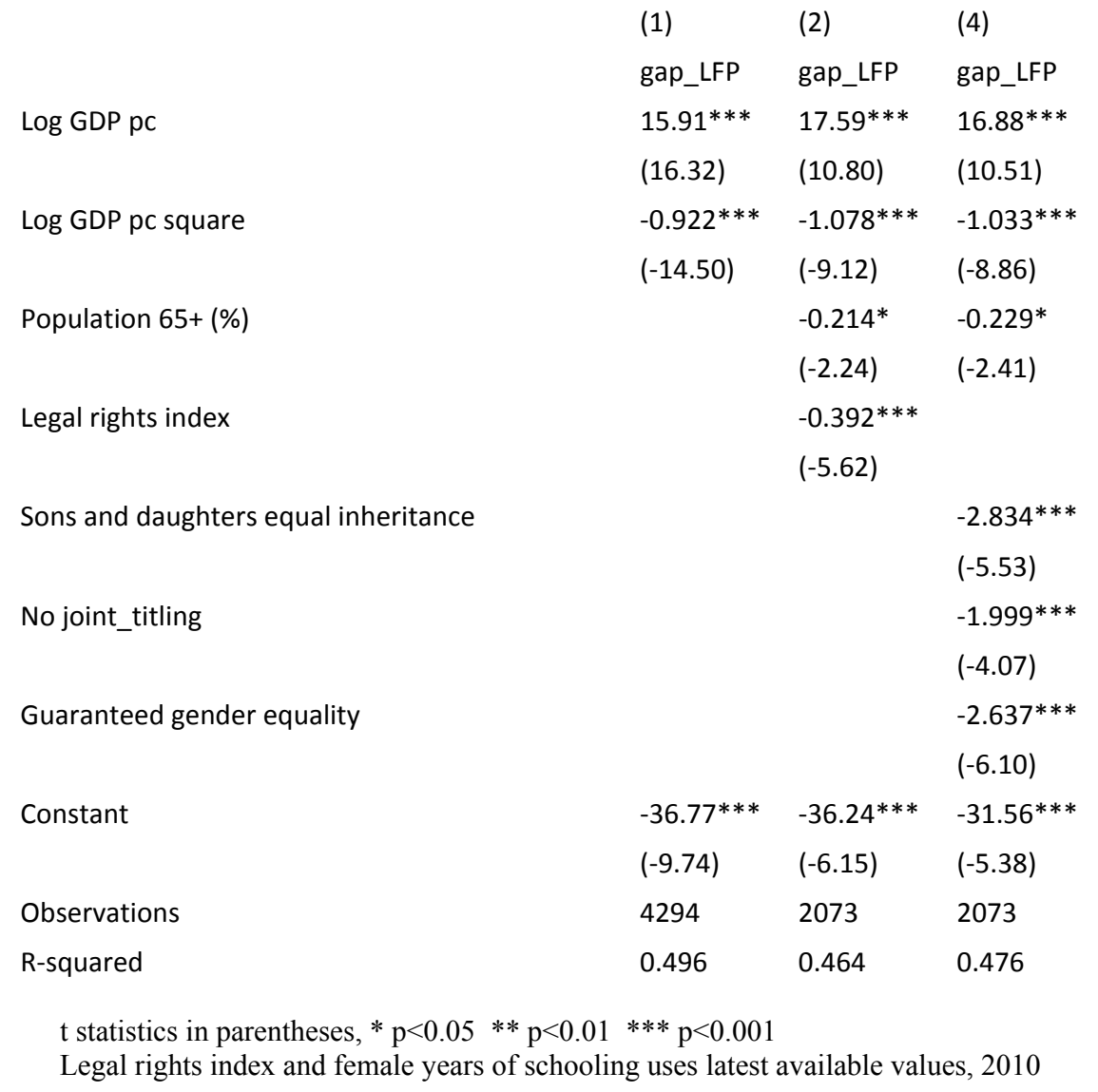

\footnotetext{
${ }^{8}$ Women's years of schooling (Barro-Lee) are available historically, but not at annual frequency needed in the panel regression. Policy variables from Women, Business and the Law (2016) are only available in 2010, 2012, 2014 and 2016.
} 
In our simple cross-country regressions, female education is also negatively associated with the gender gap in LFP, as expected, however, the relationship is statistically significant only at the 10 percent level (see Table 2). Nevertheless, several studies have established a positive link between female education and female LFP (e.g., Goldin et al, 2006; Besamusca et al, 2015, Jaumotte, 2003, and Dietrich et al. 2016 using household surveys for Sub-Saharan Africa), as education allows women to fully develop their human capital potential and increase returns in the labor market. It is, thus, widely expected that policies which support women's education not only decrease the gender gap in LFP, but also promote higher levels of productivity of those women who work.

Other policies, such as childcare provision, maternity and paternity leave, tax treatment of married women, could all be important predictors of the gender gap in LFP. However, studying these policies in the cross-section is difficult, because of omitted variable bias, potential reverse causality, and the lack of time-series data which would have allowed us to control for country-specific factors. For example, the last column in Table 1 shows that the $\log$ of number of maternity days is positively related with the gender gap. This counterintuitive finding is likely driven by unobserved variables and endogeneity. It might be that there are many middle income countries, with low female LFP, which have instituted a large number of maternity leave days but the share of female workers who are eligible for these benefits is small. Furthermore, this imposition of significant maternity leave could also pose high costs for employers which, in turn, biases hiring decisions against women. Another channel is that as women work more, there is also a stronger demand for more maternity leave, thus generating this positive (endogenous) relationship. Thus, care should be exerted when examining these results in a simple cross-country setting.

For this reason, in the next subsection, we provide an overview of the literature which uses national studies and detailed household level data to analyze the effect of various policies aimed at increasing the female labor force participation rate.

\section{B. Effective policies: childcare subsidies and parental leave}

There is a large, and expanding, literature of country-level studies that evaluate policy changes related to female LFP. The type of policies considered generally fall into three main categories: leave policies, childcare subsidies, preschool programs. Most countries have some combination of these policies, and their interactions and levels all matter jointly (see Cascio et al, 2015). For example, increasing days of maternity leave may have a large positive effect on female LFP in a country with few other related benefits, but a small effect in a country with an already very generous system overall.

Childcare subsidies and vouchers are generally successful in supporting higher female LFP or increasing women's hours worked. There is supporting evidence both from Latin America 
(Table 4), as well as the rest of the world. ${ }^{9}$ In particular, the evidence has found that even if a combination of policies is necessary to incentivize women entering the labor force, childcare provision has been consistently shown as one of the most effective policies (Mateo Diaz and Rodriguez Chamussy, 2013). More generous childcare policies have also been shown to increase female labor force participation in advanced economies. ${ }^{10}$ Overall, provision of highquality childcare tends to free mothers to go back to their previous jobs, or increase the number of hours in their part-time work

Table 4. Childcare programs in LAC and their effects on female LFP and hours worked

\begin{tabular}{|llcc|}
\hline Country & Program & LFP $\uparrow$ & $\begin{array}{c}\text { Hours } \\
\text { worked } \uparrow\end{array}$ \\
\hline Guatemala & Hogares Comunitarios & No & Yes \\
Mexico & Estancias Infantiles para madres trabajadoras & Yes & Yes \\
Colombia & Hogares Comunitarios de Bienestar Familiar & Yes & Yes \\
Ecuador & Centros de desarollo infantil & Yes & \\
Chile & Chile crece contigo & Unclear & \\
Brazil & Rio de Janeiro's public daycare program & Yes & No \\
\hline
\end{tabular}

Source: Mateo Diaz and Rodriguez Chamussy, 2013.

Leave policies also tend to increase women's attachment to the labor force, but results are more context-dependent than childcare policies. Researchers have studied two types of change in leave policies: first, changing the duration of paid leave; and second, changing the income replacement rates, i.e. the proportion of their salary that women get, while on a fixed maternity leave duration. The first set of studies found that longer maternity leave tends to be associated with higher women's employment (Ruhm, 1998, Jaumotte, 2004). Lalive and Zweimuller (2009) also report that extending job-protected maternity leave from one to two years is associated with a delay in women's return to work and potential fertility increases, without finding significant long-run earnings consequences due to these extended career interruptions. Regarding replacement rates, the effects might vary depending on other policies. For example, increasing female replacement rates was shown to have only a negligible effect on mothers' job continuity rates in Japan (Asai, 2015), possibly due to insufficient childcare options which would allow women to return to work.

There are other policies, for which there is less evidence, but which may also increase female labor supply, especially of working mothers, who tend to respond to labor market or tax incentives. These include greater flexibility in work hours including the availability of

\footnotetext{
${ }^{9}$ For impact evaluations in Guatemala see Hallman et al (2015); for Mexico see Calderon (2012); for Colombia see Attanasio and Vera-Hernandez (2004); for Ecuador see Rosero and Oosterbeek (2011); for Brazil see Deutsch (1998); for Chile see discussion in Mateo Diaz and Rodriguez Chamussy, 2013.

${ }^{10}$ For impact evaluations of childcare policies in advanced countries, for example in the Netherlands see Bettendorf et al, 2015; for France see Givord and Marbot, 2015; for Italy see Del Boca, 2002; for Canada see Haeck et al, 2015 etc. Introduction of universal preschools in Spain increased mother's LFP (Nollenberger and Rodriguez-Planas, 2015).
} 
temporary part-time employment (see discussion in Jaumotte, 2004); removing the secondearner penalty from family taxation (Stotsky, 1997); and "in-work" tax credits for low wage female workers (IMF, 2013). A sensitivity to gender budgeting issues (including initiatives such as the ones Mexico, Ecuador, Bolivia, and El Salvador documented in Fragoso and Enriquez 2016) will also help not only free up fiscal resources towards gender issues but also directly ensure their allocation.

\section{MACROECONOMIC IMPACT OF INCREASING FEMALE LFP}

It is challenging to estimate the macroeconomic impact of durably increasing female LFP because long-run drivers of changes in female LFP are likely to overlap with long-run drivers of GDP. Moreover, the direction of causality between female LFP and GDP per capita is unclear (i.e. do higher levels of development lead to more women working or is it that women working generate higher levels of development?). Nevertheless, and abstracting from these concerns, we seek to provide a simple "back-of-the-envelope" estimate of the potential macroeconomic impact of increasing female LFP, based on fixed effects regressions, and assuming no change in other variables that may affect GDP. We then compare these "backof-the-envelope" calculations to model based estimates in Cuberes and Teignier (2016).

To obtain these "back-of-the-envelope" estimates, we run a fixed effects regression, over the period 1990-2014 (during which LFP data is most consistent and reliable), on an unbalanced panel of 169 countries (including 34 advanced countries, 28 LAC countries, 22 EM Asia countries, 21 MENAP countries, 40 Sub-Saharan African countries, 11 EM Europe). We regress log of GDP per capita on: (i) female LFP, (ii) fertility, (iii) inflation, (iv) FDI, and (v) trade openness. Other than female LFP, these other variables have been used in the standard growth regressions, and we also chose based on their availability for a large panel. Then, we use the estimated coefficient on female LFP to calculate, for each country, the predicted GDP per capita (and the associated percent change), if their female LFP were to increase to a certain (higher) level, holding all else constant. We choose two benchmark levels. First, we assume that each country's female LFP increases to the average female LFP of Nordic countries (61 percent, calculated using Denmark, Finland, Iceland, Norway, and Sweden), which, as a group, have the highest female LFP levels in the world. Second, we assume that each country's female LFP increases to the same level as the country's own male LFP, i.e. that gender parity in labor force participation is reached. 
Figure 12. Comparison of potential gains in GDP per capita from higher female LFP (percent change in GDP per capita)

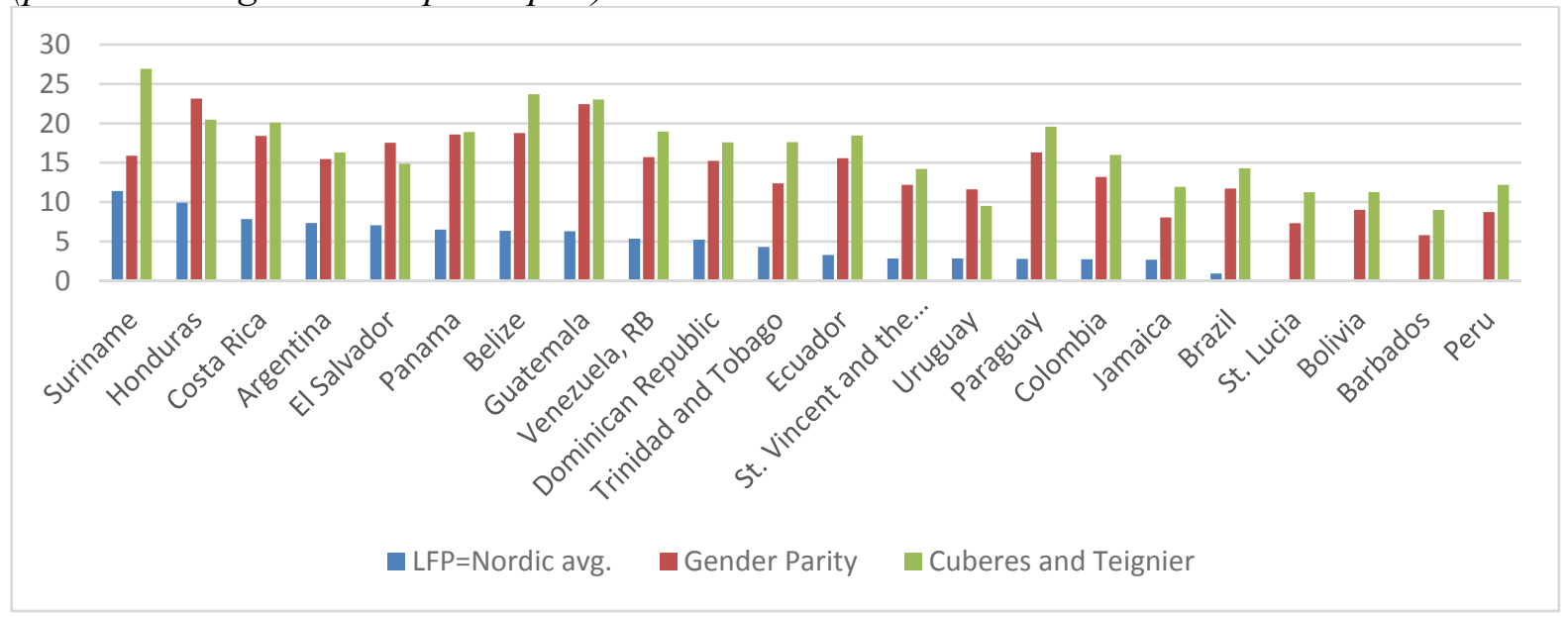

Results for individual LAC countries are shown in Figure 12. The gain in GDP from increasing female LFP to the Nordic country average could be as high as 10 percent (in Suriname), but generally depends on the country and its existing level of female LFP. ${ }^{11}$ Central American countries, which in general have lower levels of female LFP, all figure in the top 10 gainers in the region. In the exercise where we lift female LFP to equal those of men, the gains in GDP per capita are larger (as large as 20 percent in some cases), reflecting, once again, the high levels of male LFP in the region. However, this assumption that female LFP could reach current male levels with the latter remaining unchanged is likely unrealistic. If women were to enter the labor market in much larger numbers, male LFP could potentially decrease in response (especially for households which value leisure more than consumption), thus dampening the overall gain in GDP - an effect which is not captured in these simple regressions.

GDP gains estimated by Cuberes and Teignier (2016) also assume gender parity in LFP, as well as the closing other gender gaps (equal number of male and female employers, equal number of male and female self-employed). Furthermore, the authors take into account how closing these gaps affects occupational choices. Given the differences in modelling, it is interesting to note that our extremely simplistic "back-of-the-envelope" approach yields estimates of possible GDP gains that are not very different from the model-based estimates presented in Cuberes and Teignier (2016), also plotted in Figure 12. On average, our estimates suggest that LAC countries could gain between 4 and 14 percent of GDP if they reach the Nordic average for female LFP, or if gender parity is achieved, respectively.

Our findings are broadly in line with other studies on the macro-impact of higher female LFP. For example, Jacobsen (2013) estimates that higher female LFP would raise GDP per capita by about 7 percent worldwide, Aguirre estimate gains of 12 and 9 percent for

\footnotetext{
${ }^{11}$ Note that there are some LAC countries where female LFP is already higher than the Nordic average (St. Lucia, Bolivia, Barbados and Peru). In these cases, we assumed no GDP per capita gain (Figure 12).
} 
Argentina and Brazil, respectively, and Woetzel et al (2015) estimate a gain of 14 percent for Latin America.

\section{FeMALE LFP DURING ECONOMIC DOWNTURN}

Throughout the paper, we have noted that female LFP rates tend to be relatively stable and move only slowly over time. However, there are exceptions to this-female LFP may also respond to large short term changes in GDP when, for example, countries experience economic downturns. Women are typically considered the second earner in the family, and they may provide insurance to household income if the primary earner experiences unemployment. This would suggest a counter-cyclical response of female LFP, a so-called added worker effect.

Several authors have found that women's LFP responds counter-cyclically to economic shocks (see Bhalotra and Umana-Aponte, 2009, and Sabarwal et al 2010), and that this counter-cyclical response may be stronger among poorer or lower educated women, and those married to men with lower levels of income and/or education. Also, an economic downturn may negatively affect child schooling and survival in low income countries where safety nets are weak or non-existent (Sabarwal et al, 2010). In these cases, cash transfers can be an effective tool to smooth family consumption during periods of economic downturn.

Looking at specific Latin American countries, there is evidence of this higher female LFP response during past crises in Mexico in the mid-1990s (Parker and Skoufias, 2006, Cunningham, 2001, McKenzie, 2003), as well as in Peru in the early 1980s (Francke, 1992), and Argentina in the early 1990s (Cerutti 2000). Individual country-level analyses are needed to see if the global recession of 2009 has had an effect on female LFP in Latin America (for some preliminary evidence on employment see Cho and Newhouse 2013).

As in the case of analyzing specific policies, it seems most appropriate to study the effect of economic downturn using household level data in individual countries. For example, do we observe that women whose husbands lose their job are more likely to enter the labor force? Is this effect stronger during economic downturns, when the husband's probability of finding a new job is lower? This is the approach taken in Parker and Skoufias (2006) for Mexico, where they find that added worker effects are present in both normal and crisis times, but that the effect was twice as large during the Peso crisis.

If there are significant added worker effects throughout the country, then these should also be noticeable in the aggregate. We investigate this hypothesis and find some evidence, although statistical significance is weak. We ran fix effects regressions of female (or male) LFP on a dummy indicating a significant slowdown when compared to the rest of the countries in the sample ${ }^{12}$ and on the deviation of log GDP per capita from its trend (as estimated by the HP filter). We included year fixed effects and ran separate regressions for Latin America, advanced economies and EM Asia, for the period 1990-2014. Figure 13 plots the estimated coefficients for the significant slowdown dummy and the negative output gap. We see that,

\footnotetext{
${ }^{12}$ The significant slowdown dummy equals 1 if the deviation from the HP trend of log GDP per capita is in the bottom $10 \%$ of the entire sample (which includes 1990-2014, and countries in LAC, Asia and Europe).
} 
for Latin America, the results are consistent with higher LFP during significant downturns, and especially strong for women (though men in LAC are also more present in the labor force during downturns).

Figure 13: Effect of significant slowdown and negative output gap on LFP
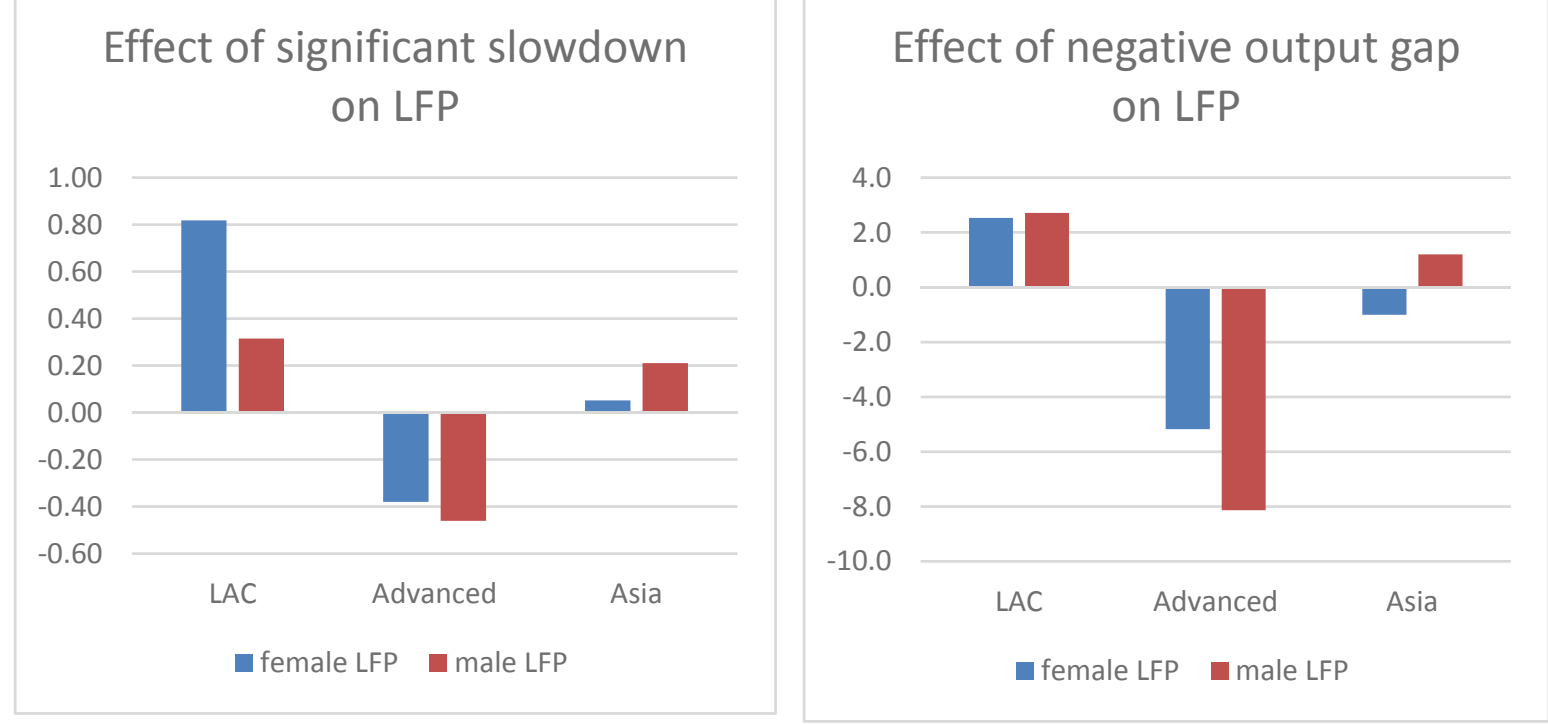

Comparing regions, we see that potential added worker effects are most pronounced in Latin America. The estimated effects in Asia are small and not statistically significant. In advanced economies where savings are higher and the safety net stronger, workers can "afford" to remain outside of the labor force during a downturn and seem to respond pro-cyclically. Of course, results presented in Figure 13 should be interpreted with caution, and offer only suggestive evidence that different mechanisms may be at play when workers make their labor supply decisions in Latin America, versus advanced economies or Asia. More detailed, household level data are needed to investigate these mechanisms in depth.

\section{Conclusions and Policy Recommendations}

Women's work remains an important untapped resource throughout the world, and LAC is no exception. In the case of LAC, where there is a need to find new sources of growth, encouraging more women to participate in the labor market would help boost income levels and employment across countries.

LAC as a region has made significant strides, which have brought female LFP rates from under 45 percent in 1990 to broadly the levels of female LFP rates in the US and emerging Asia by 2014. Many of these gains were driven by the larger South American economies, with female LFP rates in Central America still trailing behind. Our empirical findings suggest that, while economic development has likely contributed to this "catching-up", there were also other factors at play, including a higher level of educational attainment for women and equal legal rights for women and men. 
Nevertheless, the gender gap (difference between male and female LFP) within LAC countries remains sizable, despite the narrowing of the gap in female LFP between the LAC region and the rest of the world. The relatively young demographics in LAC countries means that men in LAC countries tend to participate more in the labor market then men in countries with an older population. Therefore, high male LFP partly explains the remaining gender gap in LAC countries, despite the fact that LAC women have nearly achieved parity with their world counterparts.

There are encouraging signs: just like in most of the world, women in LAC are becoming more educated than men. Younger and more educated women are working more and closing the gender LFP gap. Thus, while female LFP gains will materialize gradually, LAC appears to be on the right track. With this in mind, it is essential now to put in place policies to foster a propitious environment for women to enter and stay in the labor force. Based on our empirical work, as well as findings from the literature, these include:

- Where needed, strengthen women's legal rights, especially property rights and laws protecting women from discrimination.

- Implement/extend early childhood education and childcare services.

- $\quad$ Promote girls' education and put in place educational and job training policies to further women's higher education.

- Improve infrastructure, especially with regards to urban transportation.

The direct positive impact of women entering the labor force is only the beginning. By implementing policies that support working women, such as those mentioned above or, for example, policies that guarantee equal pay for similar work, women's power to make decisions in the household is strengthened. Given that women tend to use household resources in ways that benefit children more (e.g. children's education and healthcare, see Duflo 2012 for a literature review), this would also benefit the entire family, as well as increase labor productivity and provide a boost to the economy. 


\section{REFERENCES}

Aguirre, DeAnne, Leila Hoteit, Christine Rupp, and Karim Sabbagh, 2012, "Empowering the Third Billion. Women and the World of Work in 2012," Booz and Company.

Amin, Mohammad, Veselin Kuntchev, Martin Schmidt, 2015, "Gender Inequality and Growth," Policy Research Working Paper WPS7172, (Washington D.C.: The World Bank Group).

Asai, Yukiko. "Parental leave reforms and the employment of new mothers: Quasiexperimental evidence from Japan." Labour Economics 36 (2015): 72-83.

Attanasio, Orazio, and Marcos Vera-Hernandez. 2004. "Medium and Long Run Effects of Nutrition and Child Care: Evaluation of a Community Nursery Programme in Rural Colombia." EWP04/06, Centre for the Evaluation of Development Policies. The Institute for Fiscal Studies.

Baker, Michael, and Kevin Milligan. "How Does Job-Protected Maternity Leave Affect Mothers' Employment?" Journal of Labor Economics 26.4 (2008): 655-691.

Besamusca, Janna, Kea Tijdens, Maarten Keune, and Stephanie Steinmetz. "Working women worldwide. Age effects in female labor force participation in 117 countries." World Development 74 (2015): 123-141.

Bettendorf, Leon J.H., Jongen, Egbert L.W., Muller, Paul, 2015. Childcare subsidies and labour supply-evidence from a Dutch reform. Labour Econ. 36, 112-123.

Bhalotra, Sonia, and Marcela Umana-Aponte. "The dynamics of women's labour supply in developing countries." IZA Discussion paper No. 4879, (2010).

Black, Dan A., Natalia Kolesnikova, and Lowell J. Taylor. "Why do so few women work in New York (and so many in Minneapolis)? Labor supply of married women across US cities." Journal of Urban Economics 79 (2014): 59-71.

Çağatay, Nilüfer, and Şule Özler. "Feminization of the labor force: The effects of long-term development and structural adjustment." World development 23.11 (1995): 1883-1894.

Calderon, Gabriela. "What is Good for the Goose is Good for the Gander: The Effects of Child Care Provision in Mexico." (2012).

Canon, Maria E, Helen Fessenden, and Marianna Kudlyak. "Why are Women Leaving the Labor Force?”, Economic Brief EB15-11, Federal Reserve Bank of Richmond, 2015.

Cascio, Elizabeth U., Steven J. Haider, and Helena Skyt Nielsen. "The effectiveness of policies that promote labor force participation of women with children: A collection of national studies." Labour Economics 36 (2015): 64-71. 
Cerrutti, Marcela. "Economic reform, structural adjustment and female labor force participation in Buenos Aires, Argentina." World Development 28.5 (2000): 879-891.

Cho, Yoonyoung, and David Newhouse. "How did the great recession affect different types of workers? Evidence from 17 middle-income countries." World Development 41 (2013): 3150 .

Cubas, German. "Distortions, Infrastructure, and Female Labor Supply in Developing Countries." European Economic Review (2016).

Cuberes, David, and Marc Teignier. "Aggregate Effects of Gender Gaps in the Labor Market: A Quantitative Estimate." Journal of Human Capital 10.1 (2016): 1-32.

Cunningham, Wendy. "Breadwinner versus caregiver: Labor force participation and sectoral choice over the Mexican business cycle." The economics of gender in Mexico: Work, family, state, and market (2001): 85-132.

Currie, Janet, and Enrico Moretti. "Mother's Education and the Intergenerational Transmission of Human Capital: Evidence from College Openings." The Quarterly Journal of Economics (2003): 1495-1532.

Del Boca, Daniela. "The effect of child care and part time opportunities on participation and fertility decisions in Italy." Journal of Population Economics 15.3 (2002): 549-573.

Duflo, Esther. "Women empowerment and economic development." Journal of Economic Literature 50.4 (2012): 1051-1079.

Fragoso, Lucia Perez and Corina Rodriguez Enriquez, "Western Hemisphere: A survey of gender budgeting efforts". IMF Working paper WP/16/153.

Francke, Marfil. "Women and the Labor Market in Lima, Peru: Weathering Economic Crisis." International Center for Research on Women Seminar on Weathering Economic Crises: Women's Responses to the Recession in Latin America, Washington, DC, August. Vol. 11. 1992.

Freije, Samuel. "Informal employment in Latin America and the Caribbean: Causes, consequences and policy recommendations." Primer Seminario Técnico de Consulta Regional sobre Temas Laborales, BID, Ciudad de Panamá (2001).

Givord, Pauline, Marbot, Claire, 2015. Does the cost of child care affect female labor market participation? An evaluation of a French reform of childcare subsidies. Labour Econ. 36, 99111. 
Michele Goodwin and Allison M. Whelan, Reproduction and the Rule of Law in Latin America, 83 Fordham L. Rev. 2577 (2015).

Goldin, Claudia. The U-shaped female labor force function in economic development and economic history. No. w4707. National Bureau of Economic Research, 1994.

Goldin, Claudia, Lawrence F. Katz, and Ilyana Kuziemko. "The homecoming of American college women: The reversal of the college gender gap." The Journal of Economic Perspectives 20.4 (2006): 133-133.

Gonzales, Christian, Sonali Jain-Chandra, Kalpana Kochhar, and Monique Newiak, 2015a, "Fair Play: More Equal Laws Boost Female Labor Force Participation," IMF Staff Discussion Note 15/02, (Washington: International Monetary Fund).

Gonzales, Christian, Sonali Jain-Chandra, Kalpana Kochhar, Monique Newiak, Tlek Zeinullayev, 2015b, "Catalyst for Change: Empowering Women and Tackling Income Inequality," IMF Staff Discussion Note 15/20, (Washington: International Monetary Fund).

Greenwood, Jeremy, Boyan Jovanovic, 1990, "Financial Development, Growth, and the Distribution of Income," The Journal of Political Economy, Vol. 98, No. 5, pp. 1076-1107.

Haas, Lies1 2010. Feminist Policymaking in Chile. University Park: Pennsylvania State University Press.

Haeck, Catherine, Lefebvre, Pierre, Merrigan, Philip, 2015. Canadian evidence on ten years of universal preschool policies: the good and the bad. Labour Econ. 36, 137-157.

Hakura, Dalia, Mumtaz Hussain, Monique Newiak, Vimal Thakoor, Fan Yang, 2016, "Inequality, Gender Gaps and Economic Growth: Comparative Evidence for Sub-Saharan Africa," IMF Working Paper 16/111, (Washington D.C.: International Monetary Fund).

Hallman, Kelly, Agnes R. Quisumbing, Marie Ruel and Benedicte de la Briere. 2005. "Mothers' Work and Child Care: Findings from the Urban Slums of Guatemala City". Economic Development and Cultural Change, Vol. 53, No. 4 (July 2005), pp 855-885

Hausmann, R., Tyson, L, Zahidi, S. (2009). The global gender gap report 2009. World Economic Forum.

IMF, 2013, "Women, Work, and the Economy: Macroeconomic Gains from Gender Equity," IMF Staff Discussion Note, SDN/13/10.

Kochhar, K., Sonali Jain-Chandra, Monique Newiak, eds. 2016. Women, Work, and Economic Growth: Leveling the Playing Field. International Monetary Fund, Washington, DC.

Jacobsen, Joyce P. 2013. "Gender Inequality: A Key Global Challenge-Reducing Losses due to Gender Inequality." How Much have Global Problems Cost the World? p. 192 
Jaumotte, Florence. "Labour force participation of women." OECD Economic studies 2003.2 (2004): 51-108.

Lalive, Rafael, and Josef Zweimüller. "How does parental leave affect fertility and return to work? Evidence from two natural experiments." The Quarterly Journal of Economics (2009): 1363-1402.

Mateo Díaz, Mercedes, and Lourdes Rodriguez Chamussy. Childcare and women's labor participation: evidence for Latin America and the Caribbean. Inter-American Development Bank, 2013.

McKenzie, David J. "How do households cope with aggregate shocks? Evidence from the Mexican peso crisis." World Development 31.7 (2003): 1179-1199.

Nollenberger, Natalia, Rodríguez-Planas, Nuria, 2015. "Full-time universal childcare in a context of low maternal employment: quasi-experimental evidence from Spain". Labour Economics. 36, 124-136.

Parker, Susan W., and Emmanuel Skoufias*. "The added worker effect over the business cycle: evidence from urban Mexico." Applied Economics Letters 11.10 (2004): 625-630.

Rosero, José and Hessel Oosterbeek. 2011. Trade-offs between Different Early Childhood Interventions: Evidence from Ecuador. Tinbergen Institute Discussion Paper. TI 2011-102/3

Ruhm, Christopher J. "The Economic Consequences of Parental Leave Mandates: Lessons from Europe." The Quarterly Journal of Economics 113.1 (1998): 285-317.

Sabarwal, Shwetlena, Nistha Sinha, and Mayra Buvinic. "How Do Women Weather Economic Shocks." A Review of the Evidence', World Bank Policy Research Working Paper 5496 (2010).

Schwab, K, Samans, R, Zahidi, S, Bekhouche, Y, Padilla Ugano, P, Ratcheva, V, Hausmann, R., Tyson, L. (2015). The global gender gap report 2015. World Economic Forum.

Stotsky, Janet, How Tax Systems Treat Men and Women Differently, Finance and Development, March 1997.

Woetzel, Jonathan. The Power of Parity: How Advancing Women's Equality can Add \$12 trillion to Global Growth. eSocialSciences, 2015. 


\section{Brazil Labor Force Participation (2014)}

(Percent, by educational level, gender, and age)
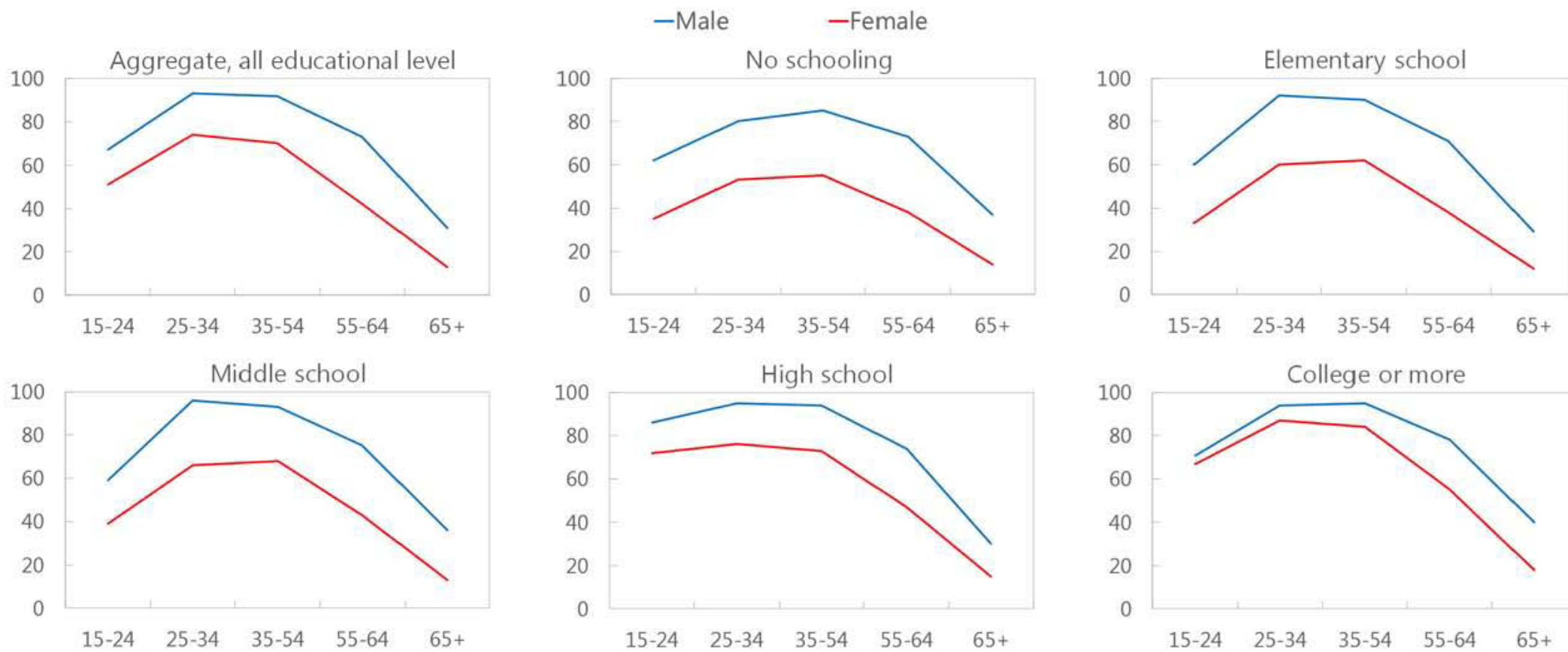

Sources: IBGE, Pesquisa Nacional por Amostra de Domicílios (2014); and IMF staff calculations.

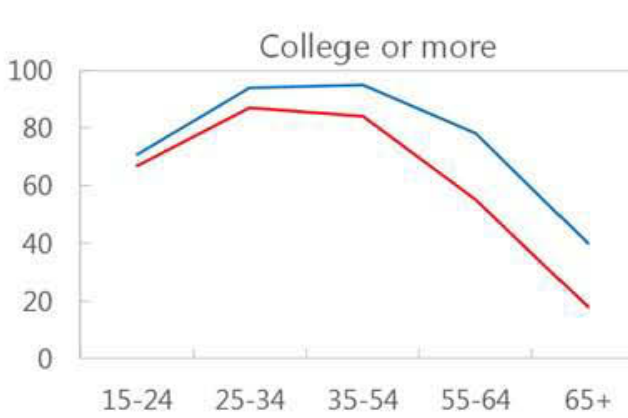


Chile Labor Force Participation (2013)

(Percent, by educational level, gender, and age)

$$
\text { -Male } \quad-\text { Female }
$$
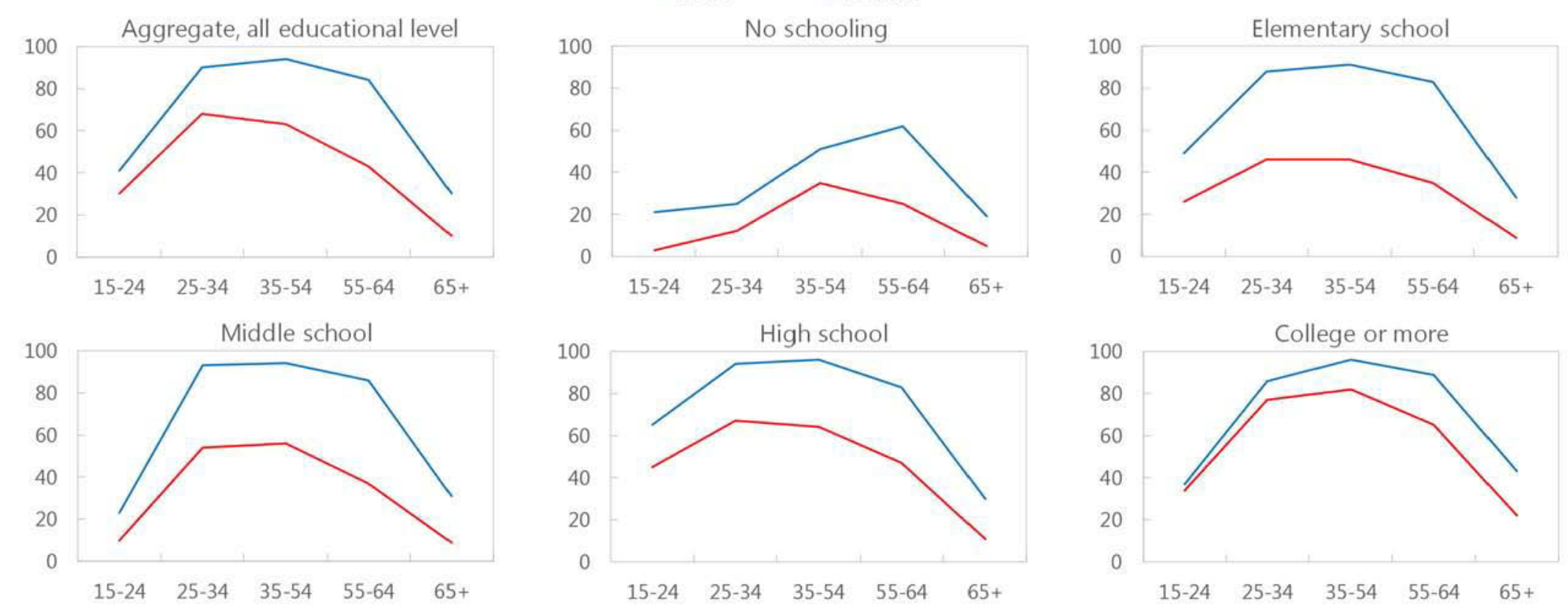

Sources: Ministerio de Desarrollo Social, Encuesta Casen 2013; and IMF staff calculations. 


\section{Colombia Labor Force Participation (2015)}

(Percent, by educational level, gender, and age)

$$
\text { -Male } \quad-\text { Female }
$$
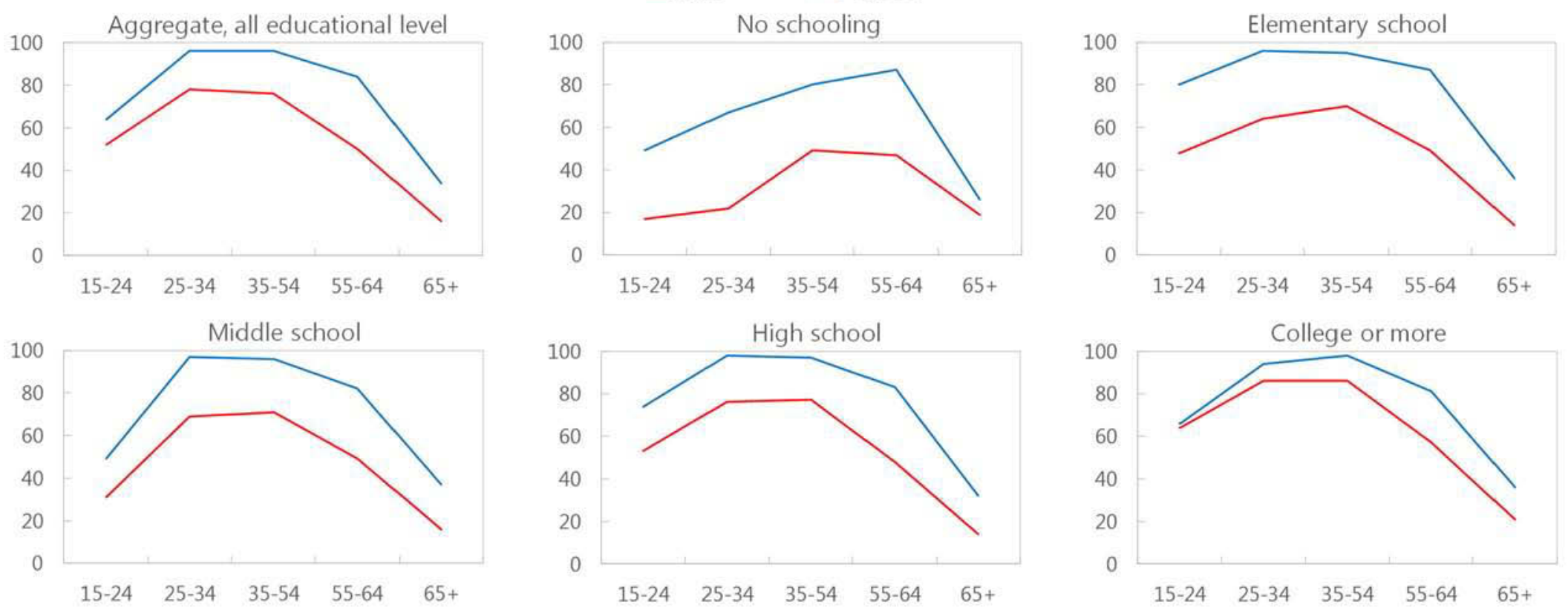

Sources: DANE, Gran Encuesta Integrada de Hogares 2015; and IMF staff calculations. 


\section{Mexico Labor Force Participation (2014)}

(Percent, by educational level, gender, and age)
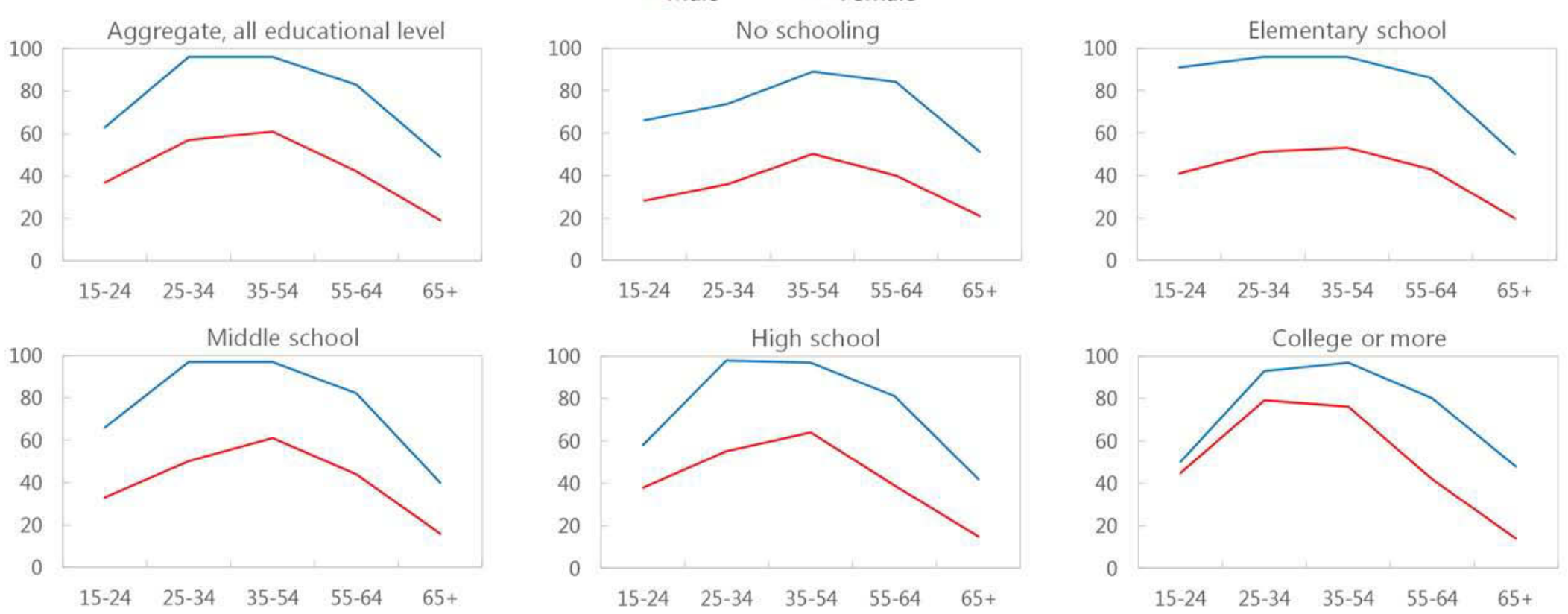

Sources: INEGI, Encuesta Nacional de Ingresos y Gastos de los Hogares (2014); and IMF staff calculations. 


\section{Peru Labor Force Participation (2015)}

(Percent, by educational level, gender, and age)

$$
\text { -Male } \quad-\text { Female }
$$
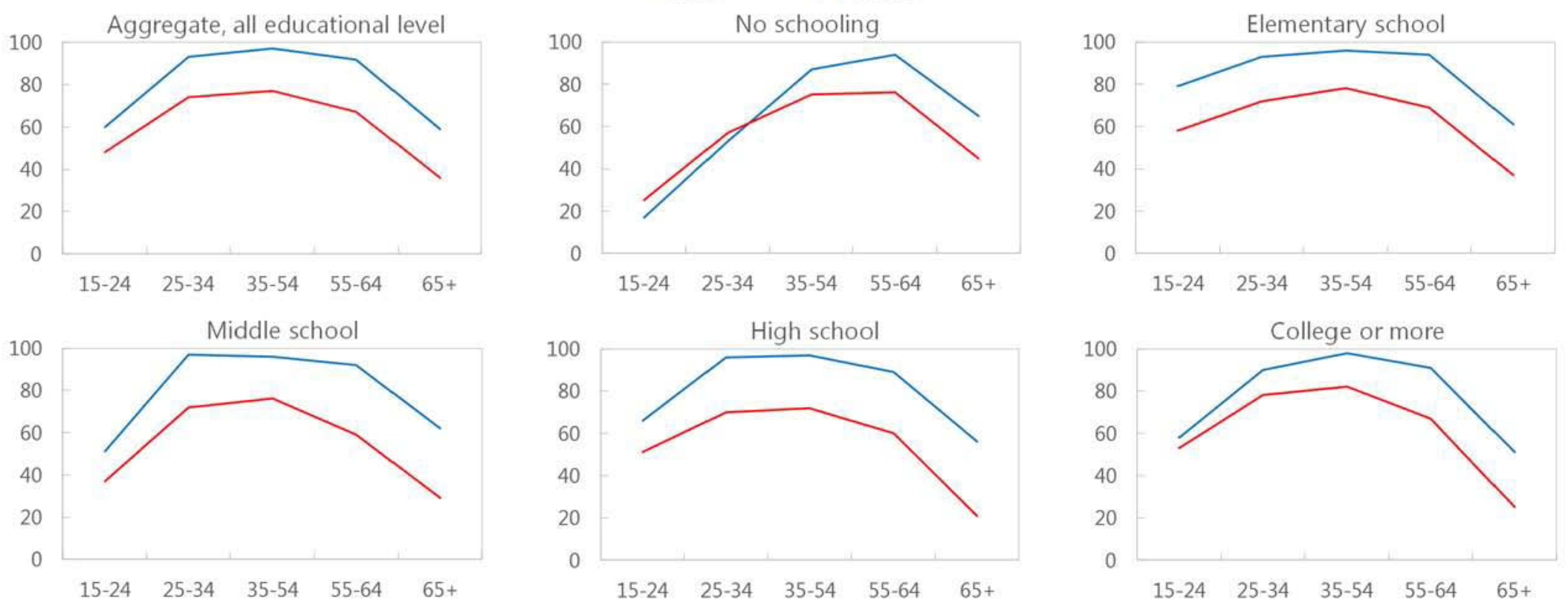

Sources: INEI, Encuesta Nacional de Hogares (2015); and IMF staff calculations. 


\section{Uruguay Labor Force Participation (2015)}

(Percent, by educational level, gender, and age)

$$
\text { -Male } \quad \text {-Female }
$$
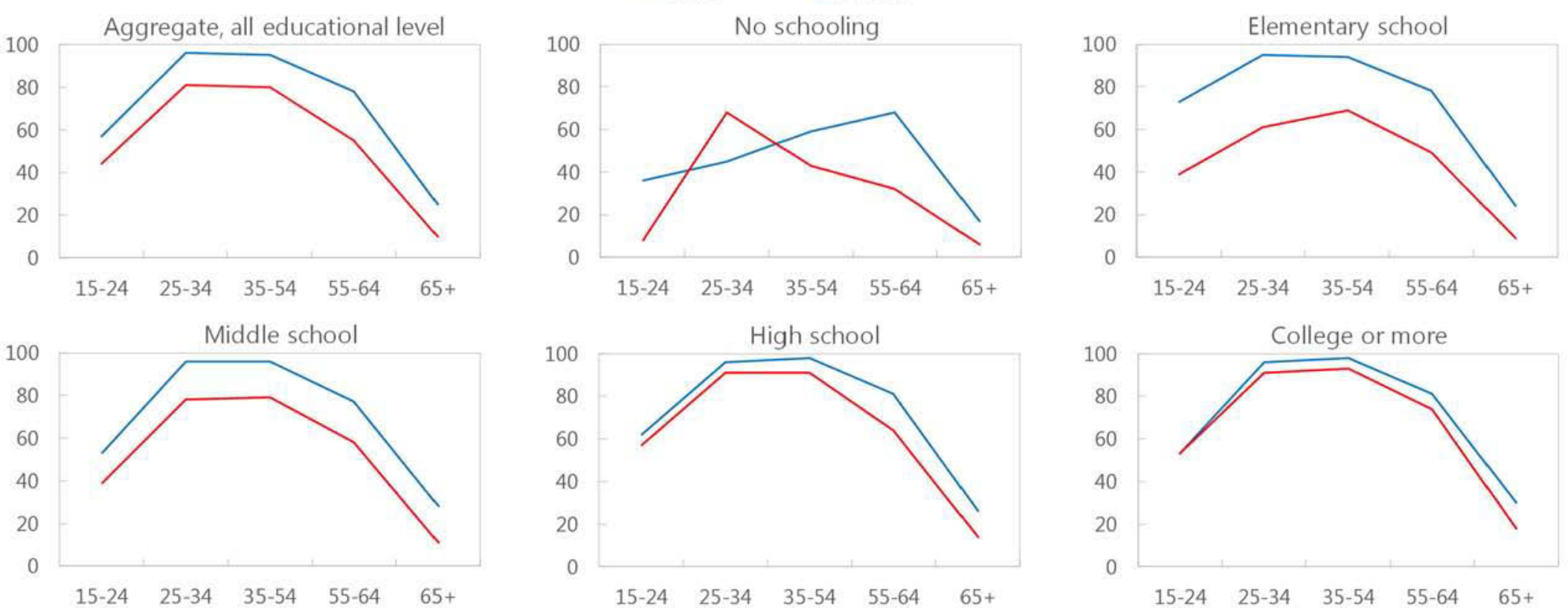

Sources: INE, Encuesta Continua de Hogares (2015); and IMF staff calculations. 


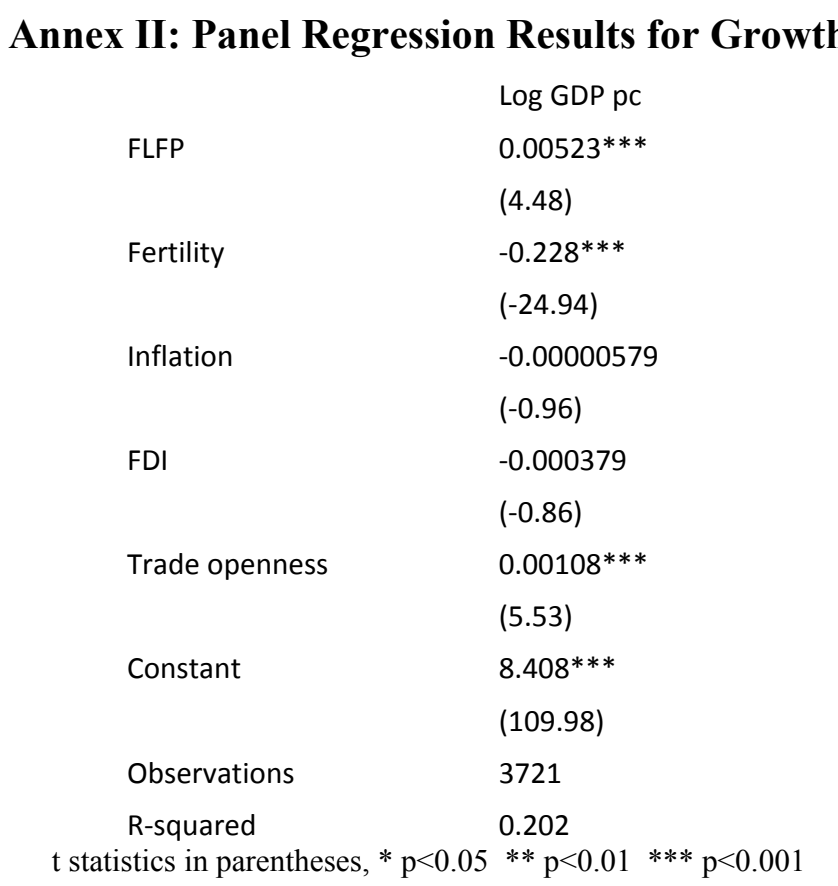

\section{Annex III: Data Sources}

1) Output (WDI): GDP per capita, constant 2005 US\$

2) Famale/male labor force participation (WDI): Female/Male labor force participation (\% of female/male population ages $15+$ )

3) Education (Barro-Lee): female years of schooling

4) Population (WDI)

5) Roads quality (World Economic Forum)

6) Legal rights index (Women, Business and the Law, 2012): subcomponents include 1) unmarried equal property rights for immoveables,2) married equal property rights for immoveables, 3) sons and daughters equal inheritance for immoveables, 4) surviving spouse's equal inheritance for immoveables, 5) no joint titling as default in married couples, 6) adult married women heal of household or head of family, 7) married women can get a job or pursue profession, 8) married women can open bank account, 9) married women can sign contract, 10) married women can initiate legal proceedings without housband's permission, 11) guarnateed gender equality by Consitution.

7) Childcare tax deductible (Women, Business and the Law, 2016)

8) Maternity leave days (Women, Business and the Law, 2016)

9) Paternity leave days (Women, Business and the Law, 2016)

10) Fertility (WDI): total births per woman

11) Inflation (WDI): consumer prices, annual \%

12) Foreign Direct Investment (WDI): net inflows, \% of GDP

13) Trade openness (WDI): Exports + imports of goods and services, \% of GDP 